\begin{tabular}{|c|l|}
\hline Title & Transient simulation of the last glacial inception. Part I : glacial inception as a bifurcation in the climate sy stem \\
\hline Author(s) & Calov, Reinhard; Ganopolski, Andrey; Claussen, Martin; Petoukhov, V ladimir; Greve, Ralf \\
\hline Citation & $\begin{array}{l}\text { Climate Dynamics, 24(6), 545-561 } \\
\text { https://doi.org/10.1007/300382-005-0007-6 }\end{array}$ \\
\hline Issue Date & $2005-05$ \\
\hline Doc URL & http://hdl.handle.net/2115/29692 \\
\hline Rights & The original publication is available at www.springerlink.com \\
\hline Type & article (author version) \\
\hline File Information & CD24-6.pdf \\
\hline
\end{tabular}

Instructions for use 


\title{
Transient simulation of the last glacial inception. Part I: Glacial inception as a bifurcation in the climate system
}

\author{
Reinhard Calov, Andrey Ganopolski, Martin Claussen, Vladimir Petoukhov \\ Potsdam Institute for Climate Impact Research, P.O. Box 601203, 14412 Potsdam, Germany \\ E-mail: calov@pik-potsdam.de \\ Ralf Greve \\ Institute of Low Temperature Science, Hokkaido University, Kita-19, Nishi-8, \\ Kita-ku, Sapporo 060-0819, Japan \\ and \\ Department of Mechanics, Darmstadt University of Technology, Darmstadt, Germany
}

We study the mechanisms of glacial inception by using the Earth system model of intermediate complexity CLIMBER-2, which encompasses dynamic modules of the atmosphere, ocean, biosphere and ice sheets. Ice-sheet dynamics are described by the 3dimensional polythermal ice-sheet model SICOPOLIS. We have performed transient experiments starting at the Eemiam interglacial, at $126 \mathrm{kyr}$ BP $(126,000$ years before present). The model runs for 26,000 years with time-dependent orbital and $\mathrm{CO}_{2}$ forcings. The model simulates a rapid expansion of the area covered by inland ice in the Northern Hemisphere, predominantly over Northern America, starting at about 117 kyr BP. During the next $7 \mathrm{kyr}$, the ice volume grows gradually in the model at a rate which corresponds to a change in sea level of $10 \mathrm{~m}$ per millennium. We have shown that the simulated glacial inception represents a bifurcation transition in the climate system from an interglacial to a glacial state caused by the strong snow-albedo feedback. This transition occurs when summer insolation at high latitudes of the Northern Hemisphere drops below a threshold value, which is only slightly lower than modern summer insolation. By performing longterm equilibrium runs, we find that for the present-day orbital parameters at least two different equilibrium states of the climate system exist - the glacial and interglacial; however, for the low summer insolation corresponding to $115 \mathrm{kyr}$ BP we find only one, glacial, equilibrium state, while for the high summer insolation corresponding to $126 \mathrm{kyr}$ BP only an interglacial state exists in the model. 


\section{Introduction}

The determination and understanding of the mechanisms of past climate changes represents a scientific challenge of its own, but it is also important for improving climate system models, which are used to assess potential future climate changes. During the past decade it has become clear that the explanation of past climates requires an integrative modelling approach based on an adequate representation of all major components of the climate system: atmosphere, hydrosphere, cryosphere, biosphere, and pedosphere. Rather complex and in many aspects realistic models of separate components of the climate system such as atmosphere, ocean, land-surface, biosphere and ice-sheet models, have been developed in recent years (cf. McAvaney et al. 2001), but their applicability for past climate simulations is still limited by high computational cost, especially when transient multi-millennial experiments are concerned. For this reason, a new class of models - Earth system models of intermediate complexity or EMICs, (Claussen et al. 2002) finds broad application for the study of palaeoclimates. Here, we use a new version of the Earth system model of intermediate complexity CLIMBER-2 to study the mechanisms of the last glacial inception.

We choose to simulate the last glacial inception to test the newly coupled atmosphereocean-land-biosphere-ice sheet model for several reasons. Glacial inception represents a rapid transition between two very different climate states, an interglacial and a glacial state, and it involves several important non-linear feedbacks such as snow and ice-albedo feedback, vegetation-atmosphere feedback, and a feedback related to the carbon cycle. Although it is generally accepted that the last glacial inception was caused by a reduction of summer insolation in the Northern Hemisphere (often referred to as the Milankovitch theory), there are still many unresolved questions.

To date, a number of attempts have been made to simulate the last glacial inception, which have involved both so-called time-slice experiments and transient experiments. Time-slice experiments with general circulation models of the atmosphere (AGCMs) or of atmosphere and ocean (AOGCMs) are primarily aimed at testing whether climate models under orbital configuration corresponding to 115 or $116 \mathrm{kyr} \mathrm{BP}$ are able to produce a cooling sufficient to initiate growth of ice sheets in North America and Eurasia. Most of such experiments were performed with atmosphere-only models, AGCMs, either with prescribed modern sea-surface conditions or coupled to a simple mixed-layer ocean model, and with prescribed modern land- 
surface cover, and $\mathrm{CO}_{2}$ concentrations ranging between the modern (330-350 ppmv) and 'early glacial' value of 240 ppmv (Royer et al. 1983; Rind et al. 1989; Mitchell 1993; Dong and Valdes 1995; Schlesinger and Verbitsky 1996; Vavrus, 1999; Vettoretti and Peltier 2003a). Some simulations also account for changes in vegetation cover either prescribed (Gallimore and Kutzbach 1996) or simulated with vegetation models (Pollard and Thompson 1997; deNoblet et al. 1996). Recently, several glacial inception experiments have been performed with AOGCMs (Khodri et al. 2001; Yoshimori et al. 2002) and a model of intermediate complexity, which includes a dynamical vegetation model in complement with atmospheric and oceanic models (Meissner et al. 2003).

Results of these time-slice experiments are rather ambiguous. Although all models simulate pronounced summer cooling over the continents in the Northern Hemisphere and increased duration of snow-cover season in response to reduced summer insolation at $115 \mathrm{kyr} \mathrm{BP}$, some models fail to simulate the appearance of perennial snow cover even in a single model grid cell. Several others (e.g. Dong and Valdes 1996; Yoshimori et al. 2002) simulate extensive areas of permanent snow cover. Moreover, the modelled areas of permanent snow cover are often in locations that differ from those in palaeoclimatic reconstructions of the nucleation centres during the last glaciation. In particular, most models tend to simulate a net accumulation of snow over northern Siberia, the Chukotka Peninsula and Alaska, rather than over north-eastern Canada, Quebec and Scandinavia, where ice sheets are believed to have first appeared during the last glacial inception (Clark et al. 1993). Since climate models are imperfect, it seems plausible that model biases affect simulation results of glacial inception. In particular, some climate models, which produce the most extensive area of permanent snow cover, are known to have cold biases at high latitudes. For example, Vettoretti and Peltier (2003a) have shown that the simulation of glacial inception is very sensitive to systematic temperature errors which occur in simulations of the modern climate state. In their experiments, a model with warm biases was unable to simulate any considerable increase of permanent snow cover, while a model with cold biases tends to reveal permanent snow cover in areas where ice sheets presumably never existed during the last glacial cycle. It has also been argued by Pollard and Thompson (1997) that GCMs might have a too coarse spatial resolution to simulate glacial inception realistically. Marshall and Clarke (1999) suggest that inclusion of a sub-grid distribution of orography is essential. Indeed, with a typical horizontal resolution of several hundred kilometres, AOGCMs do not account for the growth of glaciers and snowfields at the elevation above an averaged elevation of model grid 
cells, which is usually below the snow line for most of the mountainous regions. This in turn could lead to under-representation of the area of permanent snow cover, and, as a result, to a weaker snow-albedo feedback.

A conclusion often made based on the results of AGCM simulations of the last glacial inception is that the orbital forcing alone seems to be insufficient to cause the growth of continental ice sheets in the Northern Hemisphere (for the modern atmospheric $\mathrm{CO}_{2}$ concentration, land surface and ocean characteristics). However a reduction of atmospheric $\mathrm{CO}_{2}$ concentration in combination with oceanic and vegetation feedbacks may help at least some models to simulate the appearance of perennial snow cover for the orbital parameters corresponding to $115 \mathrm{kyr} \mathrm{BP}$. The problem with the interpretation of the results of time-slice experiments is that such experiments cannot directly be validated against palaeoclimatic data since the main assumption behind the time-slice experiments is that climate is in equilibrium with external forcings. This assumption does not hold for the glacial inception, which was a time of rapidly changing environmental conditions. Moreover, the most reliable palaeoclimatic data are related to the temporal evolution of total ice-sheet volume and other climate characteristics, which equilibrium time-slice experiments cannot provide. While results of time-slice experiments are often considered to be successful simulations of glacial inception if at least several model grid cells have a permanent snow cover, this is not sufficient to get a 40-60 m sea-level drop just within ten thousand years after the beginning of glacial inception.

Transient simulations of glacial inception or the whole glacial cycle are so far possible only with simplified models or models of intermediate complexity. Such experiments were performed during the last decade with a zonally averaged atmosphere model coupled with onedimensional (Galleé et al. 1991), two-dimensional (Marsiat 1994) or three-dimensional (Calov and Marsiat 1998) ice-sheet models. Geographically explicit energy balance models were coupled with two-dimensional (DeBlonde and Peltier 1991, 1993; Peltier and Marshall 1995), and later on with a three-dimensional thermo-mechanical ice-sheet model (Tarasov and Peltier 1997, 1999). Simulations with these models have demonstrated that properly tuned models under combined external orbital forcing and prescribed atmospheric $\mathrm{CO}_{2}$ concentration can simulate glacial-interglacial variations in global ice volume compatible with palaeoclimatic data. This set of results was an important argument in favour of the Milankovitch theory, although prescription of observed $\mathrm{CO}_{2}$ changes precludes the analysis of a causal relation between external orbital and $\mathrm{CO}_{2}$ forcing, and thus the physical explanation of the dominant 100,000-year cycle during the 
latter part of the Pleistocene. It is also important to note that the above-mentioned models treat the ocean in a very simple way, although an attempt to account for the glacial-interglacial variations in the oceanic heat transport was undertaken by DeBlonde and Peltier (1993). The first transient glacial inception experiments which explicitly includes changes in the ocean circulation and heat transport were undertaken by Wang and Mysak (2002).

Comparison of the simulations of glacial inception performed with different models reveals large differences in the rate of ice volume growth and spatial extent of simulated ice sheets. In general, they either tend to considerably underestimate the ice volume reached during inception phase (120-110 kyr BP) and simulate ice sheets restricted to the Canadian Arctic and North American Highland, or they are in better agreement with empirical estimates for the total ice volume, but primarily due to growing a huge Eurasian ice sheet. Although a number of uncertainties exist in the reconstruction of ice sheets at the time of glacial inception, it is likely that both types of model results are inaccurate.

A number of studies of glacial inception performed with models of different complexity show that orbital forcing alone is sufficient or "almost" sufficient to produce a cooling over high latitudes in the Northern Hemisphere, which could lead to growth of ice sheets on the American and Eurasian continents. At the same time, most models either underestimate the rate of initial growth of ice sheets or place them in apparently wrong places. It is not clear so far whether these problems are related to the missing feedbacks or an underestimation of the strength of the feedbacks which are represented in the model, which may be due to coarse spatial resolution, or related to systematic biases in the modern simulated climate. In any case, simulation of glacial inception remains a very valuable test both for understanding the mechanisms of climate dynamics and the climate models themselves.

In this paper we use CLIMBER-2, a fully coupled atmosphere-ocean-vegetation-inland ice model to analyse the dynamics of the last glacial inception. We argue that the glacial inception may represent a bifurcation transition in the climate system caused solely by a strong snow-albedo feedback. Although the timing and the rate of ice sheet build up are affected by other feedbacks (e.g., with vegetation and the carbon cycle), these are presumably not the primary mechanisms. Correct representation of the strength of the snow-albedo feedback would require high spatial resolution and realistic description of snow albedo, which to some extent could explain some model discrepancies mentioned above. In the accompanying paper (Calov et al. 2004, Part II), we present a detailed analysis of the role of the individual feedbacks (oceanic, 
vegetation, dust) and other factors (like changes in the ocean thermohaline circulation) in the dynamics of the last glacial inception.

\section{THE MODEL}

The CLIMBER-2 model used in this study was first presented as a coupled atmosphere-ocean model (Ganopolski et al. 1998b). Then it was extended by including terrestrial vegetation (Ganopolski et al. 1998a) and ocean carbon cycle models (Brovkin et al. 2002). In this paper, we present the next step in this development: incorporation of an inland-ice module, based on the polythermal 3-D ice-sheet model SICOPOLIS ("SImulation COde for POLythermal Ice Sheets", Greve 1997b). The integrated atmosphere, ocean and land-surface module, referred to as the climate component or the climate module of CLIMBER-2 below, as well as its performance for present-day climate are described in detail in Petoukhov et al. (2000). Its sensitivity to various climatological forcings is discussed in Ganopolski et al. (2001). The climate component has been used for variety of palaeoclimate simulations and future climate change projections. Inclusion of an ice-sheet module allows us to broaden the application of the model, and in particular, to perform transient simulations over glacial cycles. Recently, we presented a simulation of Heinrich events using SICOPOLIS with the climatological boundary conditions simulated by the CLIMBER-2 model (Calov et al. 2002). Here, we present a more extensive description of the fully coupled atmosphere-ocean-vegetation-ice-sheet model and its performance for different climate conditions.

As a compromise between computational efficiency and limitations of individual components of CLIMBER-2, several different grids are used. The atmosphere, land-surface and terrestrial vegetation models employ the same grid with latitudinal resolution of $10^{\circ}$ and longitudinal resolution of approximately $51^{\circ}$. The ocean is represented in CLIMBER-2 by a multibasin zonally-averaged model, which includes a thermodynamic sea-ice model. In longitudinal direction, the ocean model encompasses three ocean basins, with a latitudinal resolution of $2.5^{\circ}$, and 20 unevenly spaced vertical levels. The ice-sheet model has much higher resolution than the climate component of CLIMBER-2 (about one hundred kilometres, see section 2.1 for details); therefore, an interface module described below is needed to provide fully 
interactive and bi-directional interactions between the spatially coarse climate component and the relatively fine-scale ice-sheet component of CLIMBER-2.

\subsection{Ice-sheet model SICOPOLIS}

Numerous glaciation problems of the past, present and future for the Earth and also for Mars have been simulated with SICOPOLIS (Greve 1997a,b, 2000a,b; Calov et al. 1998; Greve et al. 1998, 1999; Savvin et al. 2000). SICOPOLIS is based on the continuum-mechanical theory of polythermal ice masses (Fowler and Larson 1978; Hutter 1982, 1993; Greve 1997a), which describes the material ice as a density-preserving, heat-conducting, power-law fluid with thermomechanical coupling due to the strong temperature dependence of the ice viscosity. The stressstrain-rate relation is

$$
\boldsymbol{D}=E A\left(T^{\prime}\right) \sigma^{n-1} \boldsymbol{t}^{D}
$$

where $\boldsymbol{D}$ is the strain-rate tensor, $\boldsymbol{t}^{D}$ the deviatoric part of the Cauchy stress tensor, $\sigma=\left[\operatorname{tr}\left(t^{D}\right)^{2} / 2\right]^{1 / 2}$ the effective shear stress, $n=3$ the stress exponent and $E$ the flowenhancement factor, which is equal to one for pure ice and can deviate from one due to the softening effect of impurities or induced anisotropy in the ice (Paterson 1991). Here we use $E=3$, which is a widely-used mean value for the Northern Hemisphere ice sheets. The flow-rate factor $A\left(T^{\prime}\right)$ depends on $T^{\prime}$, the temperature relative to pressure melting (see Greve et al. 1998 and references therein). We further distinguish between cold ice with a temperature below the pressure melting point and temperate ice with a temperature at the pressure melting point, the latter being considered as a binary mixture of ice and small amounts of water. The interface that separates cold and temperate ice is monitored through the use of Stefan-type energy flux and mass flux matching conditions (Greve 1997a) (this procedure is referred to as the "polythermal mode").

The ice-sheet model computes the temporal three-dimensional evolution of ice extent, thickness, velocity, temperature, water content and age for inland ice sheets. For coupling the icesheet model and the climate component, annually averaged surface-mass balance and temperature are computed at the atmosphere-ice interface by the interface module SEMI (described below in section 2.3). The geothermal heat flux, which is prescribed at the lower boundary of the ice-sheet model, is taken from data by Pollack et al. (1993). These data are interpolated, and in regions of 
missing data, the following values are filled in: $42 \mathrm{~mW} \mathrm{~m}^{-2}$ for Precambrian shields, $60 \mathrm{~mW} \mathrm{~m}^{-2}$ for Paleozoic orogenic areas, and $100 \mathrm{~mW} \mathrm{~m}^{-2}$ for Mesozoic/Cenozoic orogenic areas (Lee 1970). The global sea-level change is calculated from changes in the volume of the ice sheets in the Northern Hemisphere, which means that we neglect the change of ice volume in the Southern Hemisphere, assuming that the contributions of Antarctica and the ice in Southern America to sea-level change were small. Isostatic depression and rebound of the lithosphere due to changing ice load is described by a local lithosphere relaxing asthenosphere model (Le Meur and Huybrechts 1996), which locally balances the downward ice weight and the upward buoyancy force exerted by the fluid asthenosphere on the elastic lithosphere. The viscosity of the asthenosphere is implicitly included by introducing a delayed isostatic time lag of $\tau_{V}=3 \mathrm{kyr}$ instead of prescribing an instantaneous adjustment of the system to the local balance.

The model domain covers the extra-tropical part of the Northern Hemisphere (from $21^{\circ} \mathrm{N}$ to $85.5^{\circ} \mathrm{N}$ ). The horizontal resolution is $1.5^{\circ}$ in the longitudinal and $0.75^{\circ}$ in the latitudinal direction, so that the domain is covered by $240 \times 87$ grid points. In the vertical direction, each grid box is subdivided into 21 levels, independent of the vertical thickness of the ice sheet and with decreasing grid spacing with depth. Time steps are 1 year for the dynamic evolution (topography, velocity) and 10 years for the thermodynamic evolution (temperature, age), respectively. Because of the large CPU time requirements, the polythermal mode is switched off in the simulations conducted for this study and replaced by the simpler "cold-ice mode" (i.e., the Stefan-type conditions at the cold-temperate-transition surface are ignored, and the computed temperatures above pressure melting are artificially reset to pressure melting). Greve (1997b) demonstrates that application of the cold-ice mode instead of the polythermal mode has only a relatively small effect on the large-scale properties of the simulated ice sheet and on the basal area of temperate ice. The volume and thickness of overlying layers of temperate ice cannot be predicted accurately in the cold-ice mode. This loss of fine-structure information is accepted here.

\subsection{Coupling of ice-sheet and climate modules}

Simulation of ice-sheet dynamics under varying climate conditions requires two surface boundary conditions: annual surface-mass balance and surface temperature of the ice sheet. The method 
most often used to provide these boundary conditions in coupled climate-ice-sheet models is based on a combination of observed present-day climatology (usually temperature and precipitation) and simulated climate-model deviations of these characteristics from the presentday conditions. Calculated this way, temperature and precipitation anomalies are then corrected for changes in orography, and ablation is calculated by using a positive degree-days parameterisation (e.g. Reeh 1989). The advantage of this method, apart from its simplicity, is that it eliminates the model's biases in simulated climatological fields in the vicinity of modern climate state. This advantage becomes less obvious in the case of simulations of a climate state that is very different from the present one. Therefore, we use another approach, based on direct and physically based coupling of climate and ice-sheet components without any explicit use of an observed climatology. This procedure inevitably introduces some systematic errors for the present-day climate. Although these systematic errors are relatively small - several degrees for the temperature and less than $30 \%$ for precipitation for the major part of the Northern Hemisphere land area - they are of an order of magnitude comparable with the changes induced by orbital forcing.

The coupling between the climate and ice-sheet modules is fully interactive and bi-directional. The climate module provides the ice-sheet module with annual mean surface-mass balance and surface temperature on the fine ice-sheet grid via the interface module SEMI (see below). In turn, changes in the ice sheets affect the climate module via changes in $(i)$ the fraction of land covered by ice sheets, (ii) surface elevation, and (iii) land area due to sea-level changes. The fractions on the climate-module grid are calculated by summation of the respective ice and land areas of those grid boxes of the ice-sheet module which lie inside the climate-module grid boxes. Accordingly, the surface elevation on the climate module grid follows from the area-weighted average icesheet module surface elevations taken over the climate-module grid boxes. In the experiment presented below, we did not take into account the impact of ice sheet variations on the freshwater flux into the ocean. Instead, we use the standard surface runoff scheme employed in CLIMBER2 , which is based on the assumption that all ice sheets are in equilibrium with the climate system. Such an approach is not justified for periods of large-scale iceberg discharge (i.e. Heinrich events) or rapid melting of ice sheets, but for the glacial inception this simplification has a minor impact on the oceanic circulation and the global water cycle.

\subsection{Surface Energy and Mass balance Interface (SEMI)}


SEMI is a one-layer snow pack model, which simulates seasonal variations of snow thickness and surface temperature of ice sheets. SEMI has the same horizontal resolution as the ice-sheet model and provides the latter with annually averaged surface-mass balance and temperature. The two prognostic variables of SEMI are the thickness of snow and the surface temperature (see Appendix for a detailed description). Both of these characteristics are simulated in the same way as in the land-surface module of the climate component, but on a much higher spatial resolution. Therefore, climatological fields which are needed for the snow cover simulation - air temperature, humidity, precipitation, short-wave and long-wave radiation fluxes, wind speed - are spatially bi-linearly interpolated from the coarse grid of the atmospheric module to the fine grid of the ice sheet. The orographic effect is taken into account by using simple vertical interpolations for wind and radiative fluxes, and by using additional parameterisations for precipitation. In each grid cell which contains land surfaces, SEMI evaluates the mass balance of a virtual snow cover. If the snow cover melts completely, then the model assumes an underlying ice sheet for which the amount of melted ice is computed. The annual amount of net increase of snow thickness (i.e., positive mass balance) or net decrease of ice thickness (i.e., negative mass balance) is used as a surface boundary condition for the ice-sheet model or is ignored in cases of no ice. The annual mean temperature of the ice-sheet surface is assumed to be equal to the annual mean temperature of the snow surface. Prognostic equations for snow/ice thickness and for surface temperature are solved with a daily time step.

The only physical difference between snow and ice surfaces in the model is their surface albedo. While ice has a constant albedo of 0.4 , the albedo of snow depends on the solar zenith angle, temperature, snow age, and contamination by dust. The latter is the main novelty of our scheme. A number of palaeoclimatic records indicate that the glacial age was much more 'dusty' than interglacial periods (e.g. De Angelis et al. 1997; Petit et al 1999). Dust affects climate in several ways. Atmospheric dust increases the fraction of reflected solar radiation and thus exerts a cooling effect over the most of the Earth's surface, except for areas covered by snow and ice, where radiative forcing of dust could be positive. Recent estimates of the total radiative effect of dust at the climate conditions of the last glacial maximum (LGM) suggest that the globally averaged cooling effect of dust might be comparable to the effect of decreased atmospheric $\mathrm{CO}_{2}$ concentrations (Claquin et al. 2003), which implies that the atmospheric dust could provide an important positive feedback during glaciation. 
Secondly, dust affects climate dynamics by reducing the albedo of snow and ice. This feedback presumably is a negative one, at least at some stages of the glacial cycle, because an increase of ice volume leads to a dryer climate, to an increase of dust generation and hence, deposition, thereby lowering snow albedo and amplifying snowmelt. It has been shown by Warren and Wiscombe (1980) that even very small concentrations of dust in snow (of the order of magnitude of one part per million) could considerably decrease the albedo of snow, especially, for old snow, which has larger size of ice grains. According to simulations by Mahowald et al. (1999), dust deposition rates in some areas of northern Eurasia and North America at the LGM is rather high. This theoretical estimate would imply dust concentrations in the atmospheric of values up to $100 \mathrm{ppmv}$ (parts per million in volume equivalent) which, in accordance with Warren and Wiscombe (1980), could decrease the albedo of snow surfaces by as much as $10 \%$ for new and 30\% for old snow. In SEMI, we use a relation between the albedo of snow surfaces and atmospheric dust concentration by Warren and Wiscombe (1980). We use values for new and old snow, and we specify an aging parameter of snow as a weighting factor (see Appendix). The aging parameter of snow is a function of temperature and precipitation rate. In this study, we take into account the effect of dust on the albedo of snow surfaces only. Radiative effects of atmospheric dust are considered in an ongoing project.

\section{Evaluation of the surface interface}

It has been shown by Petoukhov et al. (2000) that CLIMBER-2, at its coarse spatial resolution, simulates modern climatology with reasonable skill. However, due to the large difference in spatial resolution between the climate component of CLIMBER-2 and SEMI (one climate grid cell covers about 500 grid cells of the SEMI model) it is not clear a priori whether the downscaling method applied here provides realistic climatological fields at the regional scale. Therefore, as a first step of the model assessment, we compare model results against modern data at the resolution of SEMI. Then, we choose the climate of the LGM, some 21,000 years ago, as a second test case, without any new calibration of the model to the new climate state. Since no direct proxies for the mass balance of the ice sheets at LGM are available, we compare our model with results from comprehensive climate models (GCMs).

\subsection{Present-day climate state}


SEMI is designed to simulate the mass balance and surface temperature of the ice sheets globally. However, since the ice-sheet model is only applied to the Northern Hemisphere, we restrict our analysis to high and middle latitudes of the Northern Hemisphere. Simulated and observed annual mean precipitation are shown in Fig. 1a, c. The overall agreement between modelled and observed precipitation is satisfactory, although there are some obvious biases. In particular, the model has a wet bias in north-eastern Eurasia. There is also too much precipitation over the Rocky Mountains and in northern North America. This is attributed to the coarse grid size of the atmospheric module, which the downscaling techniques used here cannot fully compensate. The agreement is better for the winter snow thickness (Fig. 1 b,d). This can be explained by the fact that the wet bias discussed above is primarily due to an overestimation of summer precipitation, while winter precipitation is in better agreement with observations. The model correctly reproduces a maximum in snow depth (up to $2 \mathrm{~m}$ ) over the Rocky Mountains, over the east coast of America and over Scandinavia, while the thickness of snow cover is somewhat underestimated over the central part of Eurasia.

One of the prerequisites for a successful simulation of the glacial world is a realistic representation of the mass balance of the ice sheets under modern conditions. Apart from Greenland, SEMI simulates two clusters of grid points with a positive mass balance over Ellesmere Island and Axel Heiberg Island and individual glaciated grid points over Baffin Island. These are all regions where large ice caps and glaciers exist in reality. The total area of simulated permanent snow cover in the Canadian Arctic is approximately $0.2 \times 10^{6} \mathrm{~km}^{2}$ which is close to empirical estimates (Zou and Oerlemans 1997; $0.15 \times 10^{6} \mathrm{~km}^{2}$, from table A2 by adding the values in columns 1 to 6 therein). The model does not simulate permanent snow cover over the Eurasian continent, but there are several grid points with a positive mass balance over Iceland and Svalbard. In Greenland, SEMI computes an area of positive surface-mass balance in close correspondence to the area covered by inland ice (Fig. 2a), except for the northern part of Greenland where the simulated area of positive mass balance extends up to the coastline. The model predicts a total accumulation (precipitation minus sublimation) of snow over the Greenland ice sheet of approximately $600 \times 10^{12} \mathrm{~kg} / \mathrm{yr}$, which is close to the range of empirical estimates (e.g. Weidick $1985\left(500 \times 10^{12} \mathrm{~kg} / \mathrm{yr}\right)$; Huybrechts et al. $1991\left(545 \times 10^{12} \mathrm{~kg} / \mathrm{yr}\right)$; Ohmura and Reeh $1991\left(520 \times 10^{12} \mathrm{~kg} / \mathrm{yr}\right)$; Reeh et al. $1999\left(548 \times 10^{12} \mathrm{~kg} / \mathrm{yr}\right)$, Janssens and Huybrechts $\left.2000\left(542 \times 10^{12} \mathrm{~kg} / \mathrm{yr}\right)\right)$. The total ablation corresponds to $30 \%$ of accumulation. 
This fraction is somewhat lower than given by empirical estimates of 50-60\% (Weidick 1985; Huybrechts et al. 1991; Reeh et al. 1999, Janssens and Huybrechts 2000). Unlike precipitation, ablation is much less sensitive to the model parameters, but rather sensitive to elevation within the very narrow (usually one grid cell width) ablation zone. Therefore, the reason for the underestimation of the total ablation could be the still too coarse grid of SEMI, because due to the dependence of ablation on elevation, the high ablation values on low elevation might get lost here. In particular, the southern tip of Greenland, where high ablation values appear (Zwally and Giovinetto, 2000), is resolved with four grid points in longitudinal direction only. Nonetheless, our modelled ablation (Fig. 2d) displays the main features of the net ablation by Zwally and Giovinetto (2000) in area and in magnitude. The geographical pattern of precipitation over Greenland is primarily controlled by the large-scale meridional gradient, the slope and the desertelevation effect. The minimum accumulation rate simulated over Greenland (Fig. 2c) is approximately $10 \mathrm{~cm} / \mathrm{yr}$ which is close to observations, but the location of this minimum is shifted southward as compared to empirical data (Ohmura and Reeh 1991). Maximum snowfall at the southern flank of Greenland reaches approximately $80 \mathrm{~cm} / \mathrm{yr}$, which, again, is close to empirical estimates of about $100 \mathrm{~cm} / \mathrm{yr}$ (Ohmura and Reeh 1991). Precipitation in the model is more intensive along the south-western flank of Greenland, while empirical data show maximum precipitation along the southern-eastern flank (Ohmura and Reeh 1991). This model bias is primarily attributed to the fact that the averaged direction of wind interpolated from the coarse resolution of the climate model onto the fine grid of SEMI deviates from the observed one in this region. The temperature over Greenland is primarily controlled by the elevation effect and the large-scale north-south temperature gradient simulated in the climate module. The modelled annually averaged temperature (Fig. 2b) over the central part of Greenland is approximately $30^{\circ} \mathrm{C}$, which is close to the observed values (Ohmura 1987).

To assess whether such an agreement is sufficient to yield a realistic Greenland ice sheet we performed an experiment with the interactive ice-sheet model. We build the Greenland ice sheet from ice-free initial conditions by running the coupled model for 50,000 years under constant external conditions (modern orbital configuration and pre-industrial atmospheric $\mathrm{CO}_{2}$ concentration of $280 \mathrm{ppm}$ ) until the model has reached a quasi-equilibrium state. As a consequence of the underestimation of ablation in the off-line experiment described above, the interactive model yields an area for the Greenland ice sheet which is larger than the real one by about $15 \%$. The ice volume is overestimated by $30 \%$. In particular, the western flank of the 
Greenland ice sheet extends to the coastline in the model, and only the southern and south-eastern parts of the modelled Greenland remain ice-free (compare Figs. 3a, b). The modelled ice sheet obtains a maximum elevation in the central part of some $3.2 \mathrm{~km}$, which is close to reality. However, the summit is shifted northwards by several hundred kilometres as compared to the real one.

\subsection{LGM climate}

In the frame of the Paleoclimate Modeling Intercomparison Project (PMIP), Pollard (2000) simulated the mass balance of ice sheets at the last glacial peak by using a high-resolution snowpack model and results from experiments with several atmospheric GCMs. To compare the performance of our model with that of the GCMs in the PMIP study, we set up our model simulations in line with the PMIP requirements, i.e. the atmospheric $\mathrm{CO}_{2}$ concentration was set to 200 ppmv, orbital parameters were kept at values representative of 21,000 years ago, and the Earth topography and ice sheets were prescribed following Peltier (1994). The latter has been used both in the climate component of the model, aggregated for its coarse resolution, and in SEMI by interpolation of the original Peltier's $1^{\circ} \times 1^{\circ}$ data onto the grid of our ice-sheet model. The main difference between the experiments described herein and the GCMs in the PMIP experiments is that we used a fully coupled atmosphere-ocean-vegetation model instead of prescribed sea-surface temperature (SST) and prescribed modern land-surface cover. Using an interactive vegetation model instead of prescribed modern vegetation cover results in an additional global cooling of some $0.7{ }^{\circ} \mathrm{C}$ (Ganopolski 2003).

The results of LGM climate simulations reported here are similar to those described in Ganopolski et al. (1998b), which were obtained with an early version of the CLIMBER-2 model. On global average, the simulated LGM climate is cooler than the pre-industrial climate by $5{ }^{\circ} \mathrm{C}$. The Atlantic thermohaline circulation at LGM is in the "cold" mode of operation (weaker thermohaline circulation and southward shifted area of deep water formation; for more details see Ganopolski and Rahmstorf (2001)). In this mode, the North Atlantic SST and sea-ice extent are similar to the CLIMAP reconstruction, while tropical SSTs are considerably lower than that in CLIMAP (CLIMAP project members, 1976), but in good agreement with alkenone reconstructions (Rosell-Melé et al 2004). 
In the simulations of LGM climate presented here, we did not take into account the direct radiative forcing of atmospheric dust, but we did consider the effect of dust deposition on snow albedo. To assess the effect of an elevated glacial dust deposition rate, we performed two experiments: one with a modern dust deposition rate, and the second one with a deposition rate corresponding to LGM conditions. To this end, we used annual rates of dust deposition for modern and LGM conditions simulated by Mahowald et al. (1999). Modern dust deposition has a minor effect on the snow albedo in high latitudes. Therefore the experiment with "modern dust" is directly comparable with the results presented in Pollard (2000). In our experiment, the total amount of precipitation over Greenland dropped by a factor of four as compared to pre-industrial climate. This result agrees with GCM simulations by Pollard (2000) and estimates from Greenland ice cores (Cutler et al. 1995). Ablation of the Greenland ice sheet ceased almost completely under glacial climate conditions. Simulated mass balances of the North American inland ice (NAI) and the Eurasian inland ice (EUI) are within the range of the results obtained by the GCM used in Pollard's (2000) study. The averaged accumulation rate for the NAI is $50 \mathrm{~cm} / \mathrm{yr}$ in our model, a value which is in the upper range of GCM simulations, while the accumulation rate over the EUI reaches approximately $25 \mathrm{~cm} / \mathrm{yr}$, a value in the lower range of GCM simulations.

The spatial distribution of LGM accumulation rate (Fig. 4d) shows a maximum over the southern, eastern and western flanks of the NAI and relatively high values over its central part. Over the EUI, the area of high accumulation is restricted to a narrow strip along its south-western flank. Low values are simulated over the northern and eastern parts of the ice sheet. This is due to the low evaporation over the glacial North Atlantic, which is the major moisture source for the EUI. Interestingly, in an additional experiment with warmer North Atlantic SST, which corresponds to the "warm" mode of the Atlantic thermohaline circulation (Ganopolski and Rahmstorf 2001), snowfall over the EUI was twice that in the "cold" mode, but differed little over the NAI (not shown). This experiment demonstrates the high sensitivity of the mass balance of the EUI to Atlantic surface conditions. The ablation area over the NAI is restricted to its southeastern flank, and its total mass balance is positive. In contrast, the ablation area occupies a large portion of the EUI, and, as a result, the simulated total mass balance of the EUI is strongly negative. Similar results have been obtained also in GCM simulations (Pollard, 2000). With such a strong negative mass balance (Fig 4c), the EUI should completely disappear within some 5000 years, which is apparently in disagreement with palaeoclimatic data. However, a strong negative 
mass balance does not imply that our model is unable to simulate the mass balance of the ice sheets realistically. The simulated strongly negative mass balance of the EUI is primarily caused by a large ablation over the low elevation of the southern and eastern parts of the reconstructed inland ice. A new reconstruction of LGM ice-sheet extent (Svendsen et al. 1999) shows that the eastward extent of the EUI suggested by Peltier (1994) is overestimated. This means that most of simulated negative mass balance comes from the area where no ice sheet existed during LGM. Correspondingly, the rest of the EUI should have been higher in reality than in Peltier's (1994) reconstruction. Thus, the strongly negative mass balance of the EUI simulated in our model does not imply that the existence of a large ice sheet in Eurasia at LGM conditions is incompatible with the simulated climate. In fact, in the long-term equilibrium LGM run performed with interactive ice sheets (see below), the EUI not only recovered after an initial retreat, but eventually extended well beyond the reconstructed area. This demonstrates that the mass balance of the ice sheets diagnosed with climate models only tells us a little about the long-term coevolution of climate and ice sheets in a fully coupled climate-ice-sheet model.

To assess the importance of dust deposition on the albedo of snow surfaces we performed an additional experiment with LGM dust deposition computed by Mahowald et al. (1999). Comparison of Figs. $4 \mathrm{a}$ and $4 \mathrm{~b}$ shows that an increase in dust deposition considerably reduces the area of positive mass balance between $60^{\circ} \mathrm{E}$ and $120^{\circ} \mathrm{E}$ over the south-eastern part of the EUI, which presumably did not exist, as well as in eastern Siberia and Beringia, bringing the model result into closer agreement with the reconstructed extent of LGM ice sheets (Dyke et al. 2002; Svendsen et al. 1999). The increase in dust deposition leads to the reduction of the spring and summer albedo in eastern Siberia by up to $10 \%$, thus appreciably enhancing snowmelt. The change from modern to LGM dust deposition increases the total ablation of the EUI by $20 \%$. For the NAI, however, the effect of enhanced dust deposition is rather small simply because the dust deposition rate was small in this region, according to Mahowald et al. (1999). This result suggests that an increase in dust deposition during the glacial age may serve, at least regionally, as a negative feedback by preventing an eastward expansion of the EUI.

\section{Glacial inception as a bifurcation in the climate system}

To study the mechanisms of the last glacial inception we performed a transient run with the fully coupled model from $126 \mathrm{kyr}$ BP to $100 \mathrm{kyr}$ BP, taking the equilibrium Eemian climate state as 
initial condition. The equilibrium Eemian climate was obtained by a model integration over 5000 years with orbital parameters kept fixed at values valid for $126 \mathrm{kyr} \mathrm{BP}$ and a $\mathrm{CO}_{2}$ concentration of 270 ppmv. A simulation of Eemian climate with an earlier version of the CLIMBER-2 model is described in detail in Kubatzki et al. (2000). As an initial condition for the extent and depth of the Greenland ice sheet, we use the steady-state Greenland ice sheet achieved after 50,000 years integration of the model under constant present-day climate. In the transient experiment, the orbital parameters were computed by using the algorithm by Berger (1978). In this study, we did not use the carbon-cycle module of CLIMBER-2. Instead of that, the temporal evolution of atmospheric $\mathrm{CO}_{2}$ concentration was prescribed according to Barnola et al. (1987). The dust deposition rate was held constant at modern values provided by Mahowald et al. (1999). This experiment is labelled as AOVI (ㅁtmosphere-Ocean-Vegetation-Ice sheet) in the following.

A major result of the transient run is that the model successfully simulates a rapid increase of ice volume after $117 \mathrm{kyr}$ BP (see Fig. 5c), primarily due to the build up of a large ice sheet over North America. Between 118 and 117 kyr BP the land area covered by ice increases by more than $4 \cdot 10^{6} \mathrm{~km}^{2}$ in just a few hundred years (Fig. 5b and Fig. 6), reaching approximately $30 \%$ of the area of LGM ice sheets in North America. The simulated ice growth corresponds to a sea-level drop of $10 \mathrm{~m}$ per millennium. At $110 \mathrm{kyr}$ BP, the modelled ice volume reaches approximately $4010^{6} \mathrm{~km}^{3}$, or $90 \mathrm{~m}$ in sea level equivalent. This result exceeds the highest estimates of the sea level changes during MIS 5, which are in the range of 40-60 m (e.g. Lambeck and Chappell, 2001).

Close inspection of the dynamics of ice cover during glacial inception shows that the ice caps and clusters of glaciers start to grow at around 120 kyr BP in several locations: the Canadian Arctic, the Rocky Mountains and the northern part of Quebec (in Fig. 6, the situation at $118 \mathrm{kyr}$ $\mathrm{BP}$ is shown). Around $117 \mathrm{kyr} \mathrm{BP}$, the area of land covered by ice increases rapidly during several hundred years. At 116 kyr BP, the ice covers a large portion of Canada, Alaska and the mountainous region of north-eastern Asia. Initially, the ice sheet appears to be very thin (Fig. 6b). Obviously, most of the ice is formed due to a rapid increase of the area of permanent snow cover. After this rapid transition, the area covered by ice increases only marginally, while the volume of the ice sheets increases almost linearly during the next 7000 years (Fig. 5c). By $110 \mathrm{kyr}$ BP, the thickness of the ice sheets reaches 1-2 km over most of the northern part of North America, with a maximum thickness of $3 \mathrm{~km}$ along the southern and western flanks of the ice sheet where the rate of accumulation is highest. 
Since our model consists of high-resolution and coarse-resolution components, the question arises whether the rapid increase in snow cover is associated with small-scale or largescale changes in the system. Therefore, we set up an additional transient experiment, referred to as AOV, which is similar to AOVI in all respects except for the interaction with the ice-sheet model. In experiment AOV, the area of perennial snow cover was diagnosed by SEMI on the grid of the ice-sheet model, but the results obtained by SEMI were not communicated to the coarsescale climate component. In experiment AOV, perennial snow cover does not appear in any grid cell of the climate module during the whole inception run. This is consistent with the fact that SEMI, driven by the output of the climate module, simulates only small spots of perennial snow cover on its fine grid (Fig. 7a). Close inspection of experiment AOVI reveals that the initial ice caps and clusters of glaciers appear in the coupled model only at the elevation above the averaged elevation of the coarse-resolution model.

To separate the role of ice-sheet dynamics from the snow-albedo feedback, we performed an additional experiment, referred to as AOVB ('B' stands for back coupling) in the following. In experiment AOVB, the ice-sheet module is switched off, as it is in experiment AOV. In contrast to experiment AOV, however, the area of perennial snow cover diagnosed by SEMI is fed back to the climate module. Hence the climate module interacts with SEMI via changes in surface albedo, but not via changes in ice thickness and hence surface elevation. In experiment AOVB, the model successfully simulates a glacial inception (Fig. 5b and Fig. 7b) with a rapid increase of perennial snow cover. The increase in snow cover is similar to that in experiment AOVI, but it starts about 1000 years later in experiment AOVB than in experiment AOVI (Fig. 5b). Obviously, the rapid climate transition during glacial inception must primarily be attributed to the strong positive snow-albedo feedback, while ice-sheet growth, and hence the elevation effect, plays a secondary role during the initial stage.

The situation is different after $116 \mathrm{kyr}$ BP. In experiment AOVB, the diagnosed area of perennial snow cover closely follows summer insolation and rapidly falls back to its interglacial value soon after summer insolation on boreal latitudes (Fig. $5 \mathrm{a}^{1}$ ) start to increase. In experiment AOVI, the area of ice sheets continues to grow after the minimum of summer insolation is past, and remains large till the end of the run (Fig. 5b). Thus, after ice sheets are established, their

\footnotetext{
${ }^{1}$ Our model is driven by globally and seasonally varying insolation. The insolation on the particular latitude $65^{\circ} \mathrm{N}$ is chosen here only for illustration.
} 
growth and lateral spreading provide a self-stabilising effect, keeping the climate system in the glacial state.

These experiments show that the snow-albedo feedback is the primary mechanism of the glacial inception in our model. This feedback emerges only if the snow cover and ice dynamics are described in models with sufficiently high horizontal resolution. The importance of high spatial resolution is reinforced by results of an additional experiment (not shown here), which is similar to experiment AOVB, but in which the surface elevation in SEMI is smoothed to mimic the typical horizontal resolution of GCMs of some $300 \mathrm{~km}$. The results of this experiment are similar to that of experiment AOV, i.e. the area of simulated perennial snow cover increases only a little during the minimum of summer insolation.

The rapid transition in snow cover caused by the snow-albedo feedback is associated with a bifurcation in the system. A bifurcation emerges if multiple equilibria in the system exist. To test whether our model possesses such multiple equilibria, we performed a set of long-term equilibrium experiments with the fully coupled model for three different orbital configurations corresponding to $126 \mathrm{kyr} \mathrm{BP}, 115 \mathrm{kyr} \mathrm{BP}$ and present-day orbits. The orbital configurations at 126 and 115 kyr BP do not represent the most extreme orbital parameters which occurred during the Quaternary, but the first one is rather close to the so-called "warm" orbit (maximum eccentricity, maximum obliquity, perihelion at northern summer solstice), while the second one is similar to the "cold orbit" (maximum eccentricity, minimum obliquity, perihelion at northern winter solstice). The present-day orbital configuration is not very far from the circular orbit (zero eccentricity), which is between the two extremes. All experiments were performed with atmospheric $\mathrm{CO}_{2}$ concentration set to $280 \mathrm{ppmv}$ and modern dust deposition rate. For each orbital configuration, we performed two $200 \mathrm{kyr}$ equilibrium runs; the first one starting from an ice-free Northern Hemisphere. In the second set of experiments, we used Peltier's (1994) reconstruction of LGM ice sheets as initial conditions. Results of these experiments, shown in Fig. 8, reveal that for 115 and $126 \mathrm{kyr}$ BP orbital configuration, the model attains only one equilibrium state irrespective of initial conditions. In the case of $115 \mathrm{kyr}$ BP orbital parameters, this is the glacial climate state, with huge ice sheets covering the middle and high latitudes of the Northern Hemisphere. For 126 kyr BP orbital configuration, the Northern Hemisphere is essentially icefree, except for some ice over Greenland. For the modern orbital configurations, however, the model attains two different equilibria depending on the initial conditions: one glacial and one interglacial equilibrium state. The glacial state simulated with Peltier's LGM initial conditions is 
similar to the equilibrium state obtained for $115 \mathrm{kyr}$ orbital conditions, while the interglacial state simulated with modern initial conditions is similar to the equilibrium with $126 \mathrm{kyr}$ BP orbital conditions.

Obviously, the equilibrium glacial climate states simulated for $115 \mathrm{kyr} \mathrm{BP}$ and for present-day orbital parameters cannot be compared with reality, because it takes some 50,000 years for the model to reach an equilibrium state and orbital configurations are never constant over 50,000 years. Nonetheless, these experiments show the existence of at least two different equilibria in our climate-ice-sheet model within the range of late Quaternary orbital parameters. It is noteworthy that the glacial equilibrium climate state simulated under present-day orbital configuration and pre-industrial atmospheric $\mathrm{CO}_{2}$ concentration reveals a large Eurasian ice sheet. This result is not at variance with the observation that, as discussed above, the diagnosed mass balance of the Eurasian (LGM) ice sheet prescribed based on Peltier's (1994) reconstruction was strongly negative even under much lower $\mathrm{CO}_{2}$ concentration. In fact, our model starts with a negative mass balance, which leads to a shrinking ice sheet. But as the simulation continues, the ice sheet is reorganised, attains a different shape, and grows.

\section{Discussion}

A characteristic sign of the last glacial inception found in many proxy data is a fast growth of ice sheets equivalent to some 30-60 m change in sea level between approximately 120 and $110 \mathrm{kyr}$ BP. Palaeoclimatic reconstructions also agree that most of this ice grew in North America, while Europe, Greenland and Antarctica contributed relatively little to this increase. Such rapid growth of ice volume implies that the area of the North American ice sheet had to be very large already at the early stage of glacial inception. The traditional view of glacial inception as a gradual, lateral spreading of an ice sheet from initial nucleation centres (Weertman 1964; Flint 1971) cannot explain the rapid increase of the ice-sheet area and is, thus, at variance with empirical estimates of sea-level changes. In many previous simulations of glacial inception, the amount of ice was considerably smaller than indicated by proxy data, and if the rate of ice-volume growth was reproduced successfully, most ice was formed in northeast Asia, but not in North America (e.g., Marsiat 1994; Calov and Marsiat 1998). 
The main reason for the successful simulation of glacial inception presented here is the rapid increase of the ice area in North America, caused by a strong snow-albedo feedback. In our model, the glacial inception is a bifurcation transition in the climate system which occurs when summer insolation drops below some threshold value. This instability resembles the so-called small ice cap instability (see North 1984) with an important difference: in North's (1984) energy balance model, two stable equilibrium states emerge, a fully glaciated state and an ice-free state. Any small ice cap grows on a third, but unstable, nearly ice-free equilibrium. In our model, three equilibrium states appear in the transition from an interglacial to a glacial: the interglacial state with an ice-covered Greenland, the glacial state which corresponds to, but exceeds, the last glacial maximum, and the fully ice-covered, snowball-like Earth (not shown here). Hence the bifurcation diagrams of North's (1984) energy balance model and our model of intermediate complexity differ considerably.

It is well known that for strongly non-linear behaviour, the model response is very sensitive to model parameters such as spatial resolution as discussed above. We speculate that the failure of some climate models to successfully simulate a glacial inception is due to their coarse spatial resolution or climate biases, that could shift their threshold values for the summer insolation, corresponding to the transition from interglacial to glacial climate state, beyond the realistic range of orbital parameters. Another important factor determining the threshold value of the bifurcation transition is the albedo of snow. In our model, a reduction of averaged snow albedo by only $10 \%$ prevents the rapid onset of glaciation on the Northern Hemisphere under any orbital configuration that occurred during the Quaternary. It is worth noting that the albedo of snow is parameterised in a rather crude way in many climate models, and might be underestimated. Moreover, as the albedo of snow strongly depends on temperature, the underrepresentation of high elevation areas in a coarse-scale climate model may additionally weaken the snow-albedo feedback.

We consider our transient experiment to be a "successful" simulation of glacial inception, because our model apparently simulates the right timing and magnitude of the ice-sheet growth in North America (see the solid line in Fig. 5c). Recently, Wang and Mysak (2002) simulated a similar but two times smaller increase in ice volume in North America; a result which might be due to the exclusion of dynamic vegetation in their model. An improvement of their model is on its way. Obviously, our model has deficiencies too. First of all, the rate of the Northern Hemisphere ice-volume growth exceeds the upper range of empirical estimates. The primary 
reason for this is the growth of large ice sheets in eastern Siberia and Alaska, which is at variance with palaeoclimatic reconstructions. The problems regarding these two regions is not new in simulations of glacial inception. In fact, a number of climate and climate-ice-sheet models tend to simulate a considerable increase of perennial snow cover and/or ice-volume growth in these areas (Dong and Valdes 1995; Schlesinger and Verbitsky 1996; Pollard and Thompson 1997; Vettoretti and Peltier 2003a; Marsiat 1994; Calov and Marsiat 1998; Yoshimori et al. 2002; Meissner et al 2003). This is not surprising because for modern climate conditions (i.e., insolation, atmospheric $\mathrm{CO}_{2}$ concentration and dust deposition), these areas are indeed the most sensitive areas to a potential glacial inception because of their low summer temperatures, relatively high precipitation and large areas occupied by mountains. Why these potentially sensitive areas were ice-free during the whole glacial cycle is not well understood. Possible explanations may involve reorganisation of the eddy-energy and momentum transport into the high latitudes under glacial conditions (e.g. Vettoretti and Peltier, 2003b).

Another problem of our transient simulation is that the ice volume continues to grow after 110 kyr BP, while reconstructions of sea-level change, particularly those based on coral data (Bard et al. 1990; Chappell et al. 1996; Gallup et al. 2002), indicate that the ice volume declined considerably after $110 \mathrm{kyr}$ BP in response to the increasing summer insolation. This underestimation of ice-volume sensitivity to the precessional cycle is also typical for climate-icesheet models. A notable exception is the LLN climate model (Gallée et al. 1991), which, on the contrary, overestimates the amplitude of ice-volume variation in response to precessional forcing. One possible reason for the rather low sensitivity of many ice-sheet models to variations in summer insolation might be that ice-sheet models simulate too thick ice sheets with very small ablation areas. We assume that the latter problem could be related to the underestimation of icesheet mobility caused by neglecting sub-grid processes, such as ice streams and high basal sliding. As has been shown by Calov et al. (2002), the latter process could be an important factor in ice-sheet dynamics.

\section{Summary and conclusions}

1. We have coupled CLIMBER-2, an atmosphere-ocean-vegetation model of intermediate complexity, to the high-resolution ice-sheet model SICOPOLIS. The integrated model is, in 
principle, capable of simulating glacial-interglacial variations of the physical climate system. CLIMBER-2 is coupled to the ice-sheet model via a surface interface module, referred to as SEMI. SEMI provides by-and-large realistic surface boundary conditions for the ice-sheet model under interglacial and glacial climate conditions. We explicitly take into account changes in dust deposition which alterate the albedo of snow surfaces. Changes in snow albedo turn out to be an important factor affecting the mass balance of ice sheets.

2. With prescribed external forcing, i.e., changes in orbital parameters and hence seasonal insolation patterns, and prescribed atmospheric $\mathrm{CO}_{2}$ concentration, the coupled model yields an interglacial-glacial transition at around $117 \mathrm{kyr}$ BP. The glacial inception starts with the appearance of small ice caps in the Canadian Arctic and Quebec. Around $118 \mathrm{kyr}$ BP, the area of permanent snow cover in the Northern Hemisphere increases rapidly. Most ice is formed in northern North America, but an "erroneous" ice sheet is simulated over eastern Siberia and Alaska. This shortcoming leads to an overestimation of the total ice growth during the last glacial inception compared to palaeoclimatic reconstructions.

3. Our results suggest that a reduction of summer insolation in the high latitudes of the Northern Hemisphere at the end of the Eemian interglacial is the primary factor which triggers the onset of Northern Hemisphere glaciation. In our simulations, the glacial inception emerges as a bifurcation transition in the climate system, caused by strong positive snow-albedo feedback; small patches of ice sheet appear at high altitudes, which then rapidly spread over northern North America. We have shown also that there is a range of orbital parameters for which two different equilibrium-climate states can be obtained depending on the initial conditions.

4. In our model, the last glacial inception is a strongly non-linear process, which occurs when orbital forcing crosses some threshold. Such a type of behaviour is difficult to simulate because unlike a linear response - even small quantitative differences between models may lead to a completely different qualitative behaviour. In particular, a moderate underestimation of the strength of related positive feedback, for instance due to coarse spatial resolution or low albedo values, might lead to a shift of the threshold value beyond the range of orbital variations in which glacial inception did occur. 


\section{Acknowledgments}

We wish to thank Natalie Mahowald who generously provided us with the present-day and LGM dust distributions. We thank two anonymous referees whose valuable comments improved our earlier manuscript. Alison Schlums helped in editing our manuscript. This work was supported by the Deutsche Forschungsgemeinschaft (research grant CL 178/2-1 and CL 178/2-2). 


\section{Appendix}

\section{a) Governing equations of SEMI}

The surface interface module, SEMI, is based on two prognostic equations for the surface temperature $T_{s}$ and the snow thickness in water equivalent $h_{w}$ :

$$
\begin{gathered}
c_{i} \frac{d T_{s}}{d t}=S_{a b s}+R^{\downarrow}-R^{\uparrow}-H-L E, \\
\rho_{w} \frac{d h_{w}}{d t}=P_{s}-A-E
\end{gathered}
$$

where $c_{i}$ is the effective heat capacity of snow or ice surface, $\rho_{w}$ is the water density. $S_{a b s}$, $R^{\downarrow}, R^{\uparrow}, H$ and $L E$ are the absorbed short-wave solar radiation, downward long-wave, upward long-wave radiation, sensible and latent heat fluxes, respectively. Eq. (2) includes snowfall $P_{s}$, ablation $A$ and sublimation $E$. Ablation is computed from the energy balance equation (1), if the surface temperature $T_{s}$ exceeds the melting point. Unlike Wang and Mysak (2002), our model does not include parameterisations for freezing of rain or refreezing of melt water. The amount of absorbed solar radiation is computed by using two-band representation:

$$
S_{a b s}=S_{I}^{\downarrow} \alpha_{I}+S_{V}^{\downarrow} \alpha_{V}
$$

where $S_{I}^{\downarrow}$ and $S_{V}^{\downarrow}$ are the downward fluxes of near-infrared and visible radiation, respectively. Correspondingly, $\alpha_{I}$ and $\alpha_{V}$ are the surface albedos in near-infrared and visible bands. Downward short- and long-wave fluxes near the surface are computed by a spatial horizontal (bilineal) and linear vertical interpolation of the corresponding fluxes computed by the radiative scheme of the climate module.

Sensible heat flux and sublimation are computed following the standard bulk-formulas as

$$
H=C_{M} c_{p} \rho_{a} u_{s}\left(T_{s}-T_{a}\right), \quad E=C_{M} \rho_{a} u_{s}\left(Q_{s a t}\left(T_{s}\right)-Q_{a}\right)
$$


where $C_{M}$ is the heat and moisture exchange coefficient which depends on atmospheric stratification. $\rho_{a}$ and $c_{p}$ are the near-surface air density and specific heat, respectively, $u_{s}$ is the surface wind speed, $T_{s}$ and $T_{a}$ are the surface and near-surface air temperatures, respectively, $Q_{a}$ the surface air specific humidity, and $Q_{\text {sat }}$ the saturated specific humidity at the temperature $T_{S}$.

The snowfall $P_{S}$ is computed by using the total precipitation interpolated from the climate module via

$$
P_{s}=\tilde{P} p_{1}\left(T_{a}\right) p_{2}(z)\left[1+k_{1}\left(\boldsymbol{u} \cdot \nabla z_{i}+k_{2} u_{s n}\left|\nabla z_{i}\right|\right)\right]
$$

where $\tilde{P}$ is the horizontally interpolated total precipitation from the climate module, $k_{1}=0.5 \mathrm{~m}^{-1} \mathrm{~s}$ and $k_{2}=0.4$ are empirical parameters. The fraction of total precipitation in solid form (i.e. snowfall) $p_{1}$ is a continuous function of air temperature:

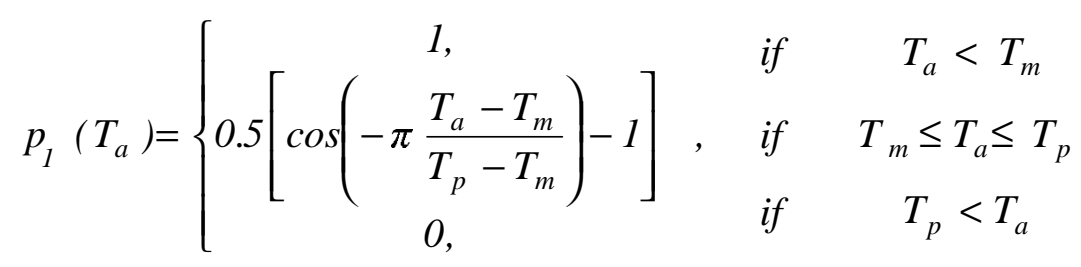

where $T_{m}=-5^{\circ} \mathrm{C}$ and $T_{p}=5^{\circ} \mathrm{C}$. In Eq. (5) $p_{2}$ represents the so-called "elevation-desert effect," parameterised by

$$
p_{2}(z)=\left\{\begin{array}{lll}
1 & \text { if } & z \leq H_{B} \\
\exp \left(\frac{z-z^{\prime}}{H_{b}}\right) & \text { if } & z>H_{B}
\end{array}\right.
$$

where $H_{b}=1500 \mathrm{~m}$, and $z^{\prime}$ is an averaged spatially interpolated elevation used in the climate component of the model.

The last term in the right hand-side of Eq. (5) represents the slope effect (e.g. Liljequist and Cehak 1974). In previous parameterisations of the slope effect, enhanced precipitation is assumed over any slope irrespective of the wind direction. Here we take into account the difference between up- and down-wind effects by including the term $\mathbf{u} \cdot \nabla z_{i}$ (Eq. 5), which represents the vertical component of wind arising from the topography. $\mathbf{u}$ is the averaged wind vector, and $\nabla z_{i}$ is the gradient of surface elevation. Because the climate component of 
CLIMBER-2 calculates only a climatologically averaged wind vector, synoptic variability of the wind vector is taken into account by adding the term $k_{2} u_{s n}\left|\nabla z_{i}\right|$ to Eq. 5, where $u_{s n}$ is the norm of the synoptic component of the wind, computed in the climate module (see Petoukhov et al, 2000). This term, unlike the previous one, is always positive, and thus increases precipitation over the slope.

\section{b) Albedo of snow surfaces}

The albedo of snow surfaces is calculated in two steps. Firstly, the albedo of snow for diffusive radiation is computed for two spectral bands - visible and near-infrared, taking into account the effects of snow aging (growth of snow grains) and contamination of snow by dust as

$$
\alpha_{d k}=\alpha_{n k}-f_{a} \beta_{k}-\delta \alpha_{k},
$$

where the index $k=1$ refers to visible radiation, and $k=2$ to the near-infrared band, respectively. Further, $\alpha_{n k}$ is the albedo of new snow. The non-dimensional effective age of snow $f_{a}$, ranging between 0 and 1 , is a function of surface temperature and precipitation. $\beta_{k}$ is the maximum reduction of snow albedo due to aging of snow, and $\delta \alpha_{k}$ is an additional reduction of snow albedo due to contamination by dust. The effect of dust deposition on snow albedo is assumed to take the form

$$
\delta \alpha_{k}=f_{a} \delta \alpha_{n k}+\left(1-f_{a}\right) \delta \alpha_{o k}
$$

where $\delta \alpha_{n k}$ and $\delta \alpha_{o k}$ are the reductions of snow albedo due to dust for new and old snow, respectively. Both factors are functions of dust concentration on the snow surface. These factors are derived from theoretical calculations by Warren and Wiscombe (1980). The concentration of dust in snow $n_{d}$ is assumed to be equal to the dust concentration in precipitation $n_{d}=\frac{d}{P}$, where $d$ is the dust deposition rate and $P$ is the total precipitation.

For clear-sky conditions, the albedo of snow is computed as

$$
\alpha_{c k}=\alpha_{d k}+0.4 f(\theta)\left(1-\alpha_{d k}\right)
$$


where $\theta$ is the averaged daily solar zenith angle, and $f(\theta)=\max \left(1, \frac{3}{1+2 \cos \theta}-1\right)$.

The averaged albedo of snow $\alpha_{k}$ is computed as a weighted sum of diffusive and clear sky albedo

$$
\alpha_{k}=n_{c} \alpha_{d k}+\left(1-n_{c}\right) \alpha_{c k}
$$

where $n_{c}$ is the cloud fraction.

\section{c) Mass balance and interval of interchange}

After the ice-sheet module has simulated the orography and the distribution of ice sheets (see section 2.2), one year of integration of SEMI (with a one-day time step) elapses, and SEMI provides the mass balances for the ice-sheet module. If a grid cell is covered by ice, then the change in mass balance, either positive or negative, is applied to the ice-sheet model in the subsequent year. If there is no ice in a grid cell, but SEMI predicts positive mass balance, then this grid cell in the ice-sheet model is treated as ice-covered in the succeeding year. If ice does not exist in the given grid cell and mass balance is negative, then the grid cell is considered to be ice-free in the succeeding year. A special case is a grid cell with negative mass balance which has a neighbouring grid cell covered by ice: if the absolute value of mass balance exceeds the amount of lateral transport of ice to the given grid cell, then ice does not appear, but melting is taken into account. In these grid points ("hidden ablation" area) SEMI computes only a potential mass balance, while the actual mass balance is calculated as the amount of melted ice, which is equal to the lateral ice inflow into this grid cell. This actual mass balance in the "hidden ablation" area is used for calculation of the total mass balance of the ice sheets. 


\section{References}

Bard E, Hamelin B, Fairbanks RG (1990) U-Th ages obtained by mass spectrometry in corals from Barbados: sea level during the past 130,000 years. Nature 346: 456-458

Barnola JM, Raynaud D, Korotkevich YS, Lorius C (1987) Vostok ice core provides 160,000-year record of atmospheric $\mathrm{CO}_{2}$. Nature 329: 408-414

Berger A (1978) A simple algorithmen to compute long term variations of daily or monthly insolation, Contribution $n^{o} 18$, Institut d'Astronomie et de G'eophysique G. Lemaître, Université catholique de Louvain, Lovain-la-Neuve

Brovkin V, Bendtsen J, Claussen M, Ganopolski A, Kubatzki C, Petoukhov V, Andreev A (2002) Carbon cycle, vegetation and climate dynamics in the Holocene: Experiments with the CLIMBER-2 model. Global Biogeochemical Cycles, 16 (4): 1139, DOI:10.1029/2001GB001662.

Calov R, Savvin AA, Greve R, Hansen I, Hutter K (1998) Simulation of the Antarctic ice sheet with a three-dimensional polythermal ice-sheet model, in support of the EPICA project. Ann Glaciol 27: 201-206

Calov R, Marsiat I (1998) Simulations of the Northern Hemisphere through the last glacialinterglacial cycle with a vertically integrated and a three-dimensional thermomechanical ice sheet model coupled to a climate model. Ann Glaciol 27: 169-176

Calov R, Ganopolski A, Petoukhov V, Claussen M, Greve R (2002) Large-scale instabilities of the Laurentide ice sheet simulated in a fully coupled climate-system model. Geophys Res Lett 29: 2216, DOI 10.1029/2002GL016078

Calov R, Ganopolski A, Petoukhov V, Claussen M, Brovkin V, Kubatzki C (2005) Transient simulation of last glacial inception. Part II: Sensitivity and feedback analysis. Clim Dyn: revised.

Chappell J, Omura A, Esat T, McCulloch M, Pandolfi J, Ota Y, Pillans B (1996) Reconciliation of late Quaternary sea levels derived from coral terraces at Huon Peninsula with deep sea oxygen isotope records. Earth Planet Sci Lett 141: 227-236

Claquin T., Roelandt C, Kohfeld KE, Harrison SP, Tegen I, Prentice IC, Balkanski Y, Bergametti G, Hansson M, Mahowald N, Rodhe H, Schulz M (2003) Radiative forcing of climate by ice-age atmospheric dust. Clim Dyn 20: 193-202 
Clark PU, Clague JJ, Curry BB, Dreimanis A, Hicock SR, Miller GH, Berger GW, Eyles N, Lamothe M, Miller BB, Mott RJ, Oldale RN, Stea RR, Szabo JP, Thorleifson LH, Vincent JS (1993) Initiation and development of the Laurentide and Cordilleran ice sheets following the last interglaciation. Quat Sci Rev 12: 79-114

Claussen M, Mysak LA, Weaver AJ, Crucifix M, Fichefet T, Loutre MF, Weber SL, Alcamo J, Alexeev VA, Berger A, Calov R, Ganopolski A, Goosse H, Lohman G, Lunkeit F, Mokhov II, Petoukhov V, Stone P, Wang Zh (2002) Earth system models of intermediate complexity: closing the gap in the spectrum of climate system models. Clim Dyn 18(7): 579-586

CLIMAP project members (1976) The surface of the ice-age earth. Science 191: 1131-1137

Cutler NN, Raymond CF, Waddington ED, Meese DA, Alley RB (1995) The effect of icesheet thickness change on the accumulation history inferred from GISP2 layer thicknesses. Ann Glaciol 21: 26-32

De Angelis M, Steffensen JP, Legrand M, Clausen H, Hammer C (1997) Primary aerosol (sea salt and soil dust) deposited in Greenland ice during the last climatic cycle: Comparison with east Antarctic records. J Geophys Res 102 (C12): 26,681- 26,698

Deblonde G, Peltier WR (1991) Simulations of continental ice sheet growth over the last glacial-interglacial cycle: experiments with a one-level seasonal energy balance model including realistic geography. J Geophys Res 6: 9189-9215

Deblonde G., Peltier WR (1993) Late Pleistocene ice age scenarios based on observational evidence. J Clim 6: 709-727

deNoblet NI, Prentice IC, Joussaume S, Texier D, Botta A, Haxeltine A (1996) Possible role of atmosphere-biosphere interaction in triggering the last glaciation. Geophys Res Lett 23: 3191-3194

Dong B, Valdes PJ (1995) Sensitivity studies of Northern Hemisphere glaciation using an atmospheric general circulation model. J Clim 8: 2471-2496

Dyke AS, Andrews JT, Clark PU, England JH, Miller GH, Shaw J, Veillette JJ (2002) The Laurentide and Innuitian ice sheets during the Last Glacial Maximum. Quat Sci Rev 21: 931

Flint RF (1971) Glacial and Quaternary geology. John Wiley and Sons, New York, London, Sydney, Toronto, pp481-484 
Fowler AC, Larson DA (1978) On the flow of polythermal glaciers. I. Model and preliminary analysis. Proc R Soc Lond A 363: 217-242

Gallée H, van Ypersele JP, Fichefet T, Tricot C, Berger A (1991) Simulation of the last glacial cycle by a coupled, sectorially averaged climate-ice sheet model. 1 . The climate model. J Geophys Res 96: 13,139-13,161

Gallimore RG, Kutzbach JE (1996) Role of orbital induced changes in tundra area in the onset of glaciation. Nature 381: 503-505

Gallup CD, Cheng H, Taylor FW, Edwards RL (2002) Direct determination of the timing of sea level change during termination II. Science 295: 310-313

Ganopolski A (2003) Integrative glacial modelling. Phil Trans R Soc A 361: 1871-1884

Ganopolski A, Kubatzki C, Claussen M, Brovkin V, Petoukhov V (1998a): The influence of vegetation-atmosphere-ocean interaction on climate during the mid-Holocene. Science 280 : 1916-1919

Ganopolski A, Rahmstorf S, Petoukhov V, Claussen M (1998b) Simulation of modern and glacial climates with a coupled model of intermediate complexity. Nature 391: 351-356

Ganopolski A, Brovkin V, Claussen M, Eliseev A, Kubatzki C, Petoukhov V, Rahmstorf S (2001) CLIMBER-2: a climate system model of intermediate complexity. Part II: model sensitivity. Clim Dyn 17: 735-751

Ganopolski A, Rahmstorf S (2001) Rapid changes of glacial climate simulated in a coupled climate model. Nature 409: 153-158

Greve R (1997a) A continuum-mechanical formulation for shallow polythermal ice sheets Phil Trans R Soc Lond A355: 921-974

Greve R (1997b) Application of a polythermal three-dimensional ice sheet model to the Greenland ice sheet: Response to steady-state and transient climate scenarios. J Clim 10: 901-918

Greve R (2000a) On the response of the Greenland ice sheet to greenhouse climate change. Clim Change 46: 289-303

Greve R (2000b) Waxing and waning of the perennial north polar $\mathrm{H}_{2} \mathrm{O}$ ice cap of Mars over obliquity cycles. Icarus 144: 419-431

Greve R, Weis M, Hutter K (1998) Palaeoclimatic evolution and present conditions of the Greenland ice sheet in the vicinity of Summit: An approach by large-scale modelling. Palaeoclimates 2: 133-161 
Greve R, Wyrwoll K, Eisenhauer A (1999) Deglaciation of the Northern Hemisphere at the onset of the Eemian and Holocene. Ann Glaciol 28: 1-8

Huybrechts P, Letréguilly A, Reeh N (1991) The Greenland ice sheet under greenhouse warming. Palaeogeogr, Palaeoclimatol, Palaeoecol 89: 399-412

Hutter K (1982) A mathematical model of polythermal glaciers and ice sheets. J Geophys Astrophys Fluid Dyn 21: 201-224

Hutter K (1993) Thermo-mechanically coupled ice-sheet response - cold, polythermal, temperate. J Glaciol 39(131): 65-86

Janssens I and Huybrechts P (2000) The treatment of meltwater retention in mass balance parameterizations of the Greenland ice sheet. Ann Glaciol 31: 133-140

Khodri M, Leclainche Y, Ramstein G, Braconnot P, Marti O, Cortijo E (2001) Simulating the amplification of orbital forcing by ocean feedbacks in the last glaciation. Nature 410: 570574

Kubatzki C, Montoya M, Rahmstorf S, Ganopolski A, Claussen M (2000) Comparison of a coupled global model of intermediate complexity and an AOGCM for the last interglacial. Clim Dyn 16: 799-814

Lambeck K and Chappell J (2001) Sea level changes through the last glacial cycle. Science 292: 679-686

Lee WHK (1970) On the global variations of the terrestrial heat flow. Physics of the Planet Earth and Planetary Interiors 2: 332-341

Le Meur E, Huybrechts P (1996) A comparison of different ways of dealing with isostasy: examples from modelling the Antarctic ice sheet during the last glacial cycle. Ann Glaciol 23: $309-317$

Letréguilly A, Huybrechts P, Reeh N (1991) Steady state characteristics of the Greenland ice sheet under different climates. J Glaciol 37: 149-157

Liljequist GH, Cehak K (1974) Allgemeine Meteorologie. Vieweg, Braunschweig

Mahowald N, Kohfeld KE, Hansson M, Balkanski Y, Harrison SP, Prentice IC, Schulz M, Rodhe H (1999) Dust sources and deposition during the last glacial maximum and current climate: A comparison of model results with paleodata from ice cores and marine sediments. J Geophys Res 104: 15,895-15,916

Marshall S, Clarke GKC (1999) Ice sheet inception: subgrid hysometric parameterizations of mass balance in an ice sheet model. Clim Dyn 15: 533-550 
Marsiat I (1994) Simulation of the Northern Hemisphere continental ice sheets over the last Glacial-Interglacial Cycle: experiments with a latitude-longitude vertically integrated icesheet model coupled to zonally averaged climate model. Palaeoclimates 1: 59-98

McAvaney BJ, Covey C, Joussaume S, Kattsov V, Kitoh A, Ogana W, Pitman AJ, Weaver AJ, Wood RA, Zhao Z-C (2001) Model Evaluation. Chapter 8. In: Houghton JT, Ding Y, Griggs DJ, Noguer M, van der Linden PJ, Dai X, Maskell K, Johnson CA (eds.) Climate Change 2001: The Scientific Basis. IPCC TAR, Cambridge University Press, pp 471-523

Meissner KJ, Weaver AJ, Matthews HD, Cox PM (2003) The role of land surface dynamics in glacial inception: a study with the UVic Earth System Model. Clim Dyn 21 (7-8): 515537

Mitchell JFB (1993) Modeling of paleoclimates: examples from the recent past. Philos Trans Roy Soc London B341: 267-275

North GR (1984) The small ice cap instability in diffusive climate models. J Atmos Sci 41(23): 3390-3395

Ohmura A (1987) New temperature distribution map for Greenland. Zeitschrift für Gletscherkunde und Glazialgeologie 23(1): 1-45

Ohmura A, Reeh N (1991) New precipitation and accumulation maps for Greenland. J Glaciol 37(125): 140-148

Paterson WSB (1991) Why ice-age ice is sometimes 'soft'. Cold Reg Sci Technol 20: 75-98

Peltier WR (1994) Ice age paleotopography. Science 265: 195-201

Peltier WR, Marshall S (1995) Coupled energy-balance/ice-sheet model simulations of the glacial cycle: A possible connection between terminations and terrigenous dust. J Geophys Res 100: 14,267-14,289

Petit JR, Jouzel J, Raynaud D, Barkov NI, Barnola JM, Basile I, Bender M, Chappellaz J, Davis M, Delaygue G, Delmotte M, Kotlyakov VM, Legrand M, Lipenkov VY, Lorius C, Pepin L, Ritz C, Saltzman E, Stievenard M (1999) Climate and atmospheric history of the past 420,000 years from the Vostok ice core, Antarctica. Nature 399: 429-436

Petoukhov, V., A. Ganopolski, V. Brovkin, M. Claussen, A. Eliseev, C. Kubatzki, and S. Rahmstorf (2000) CLIMBER-2: a climate system model of intermediate complexity. Part I: model description and performance for present climate, Clim Dyn 16, 1-17

Pollard D, Thompson SL (1997) Driving a high-resolution dynamic ice-sheet model with GCM climate: ice-sheet initiation at 116000 BP. Ann Glaciol 25: 296-304 
Pollard D (2000) Comparisons of ice-sheet surface mass budgets from Paleoclimate Modeling Intercomparison Project (PMIP) simulations. Global Planet Change 24: 79-106

Pollack HN, Hurter SJ, Johnson JR (1993) Heat flow from the Earth's interior: analysis of the global data set. Rev Geophys 31: 267-280

Reeh N (1989) Parameterization of melt rate and surface temperature of the Greenland ice sheet. Polarforschung 59/3: 113-128

Reeh N, Mayer C, Miller H, Højmark Thomsen H, Weidick A (1999) Present and past climate control on fjord glaciations in Greenland: Implications for IRD-deposition in the sea. Geophs Res Lett 26(8): 1039-1042

Rind D, Peteet D, Kukla G (1989) Can Milankovitch orbital variations initiate the growth of ice sheets in a general circulation model? J Geophys Res 94: 12,851-12,871

Rosell-Melé A, Bard E, Kay-Christian E, Grieger B, Hewitt C, Müller PJ, Schneider RR (2004) See surface temperature anomalies in the oceans at the LGM estimated from alkenone-U ${ }_{37}^{K}$ index: comparison with GCMs. Geophys Res Lett 31: L03208, DOI: 10.1029/2003GL018151

Royer JF, Deque M, Pestiaux P (1983) Orbital forcing of the inception of the Laurentide ice sheet. Nature 304: 43-46

Savvin AA, Greve R, Calov R, Mügge B, Hutter K (2000) Simulation of the Antarctic ice sheet with a three-dimensional polythermal ice-sheet model, in support of the EPICA project. II. Nested high-resolution treatment of Dronning Maud Land, Antarctica. Ann Glaciol 30: 69-75

Schlesinger ME, Verbitski M (1996) Simulation of glacial onset with a coupled atmospheric general circulation/mixed-layer ocean-ice sheet/asthenosphere model. Palaeoclimates 2: $179-201$

Svendsen JI, Astakhov VI, Bolshiyanov DYU, Demidov I, Dowdeswell JA, Gataullin V, Hjort C, Hubberten HW, Larsen E, Mangerud J, Melles M, Möller P, Saarnisto M, Siegert MJ (1999) Maximum extent of the Eurasian ice sheets in the Barents and Kara sea region during the Weichselian. Boreas 28: 234-242

Tarasov L, Peltier WR (1997) Terminating the 100 kyr ice age cycle. J Geophys Res 102: $21,665-21,693$ 
Tarasov L, Peltier WR (1999) Impact of thermomechanical ice sheet coupling on a model of the 100 kyr ice age cycle. J Geophys Res 104: 9517-9545

Vavrus SJ (1999) The response of the coupled arctic sea ice-atmosphere system to orbital forcing and ice motion at $6 \mathrm{kyr}$ and $115 \mathrm{kyr}$ BP. J Clim 12: 873-896

Vettoretti G, Peltier WR (2003a) Post-Eemian glacial inception. Part I: The impact of summer seasonal temperature bias. J Clim 16: 889-911

Vettoretti G, Peltier WR (2003b) Post-Eemian glacial inception. Part II: Elements of a cryospheric moisture pump . J Clim 16: 912-927

Wang Z, Mysak LA (2002) Simulation of the last glacial inception and rapid ice sheet growth in the McGill Paleoclimate Model. Geophys Res Lett 29: 2102, DOI: 10.1029/2002GL015120

Warren SG, Wiscombe WJ (1980) A model for the spectral albedo of snow. II: Snow containing atmospheric aerosol. J Atmos Sci 37:2734-2745

Weertman J (1964) Rate of growth or shrinkage of nonequilibrium ice sheets. J Glaciol 5: $145-158$

Weidick A (1985) Review of glacier changes in West Greenland. Zeitschrift für Gletscherkunde und Glazialgeologie 21: 301-309

Yoshimori M, Reader MC, Weaver AJ, McFarlane NA (2002) On the causes of glacial inception at $116 \mathrm{ka} \mathrm{BP.} \mathrm{Clim} \mathrm{Dyn} 18$ (5): 383-402

Zou Z, Oerlemans J (1997) Contribution of glacier melt to sea-level rise since AD 1865: a regionally differential calculation. Clim Dyn 13 (12): 835-845

Zwally HJ, Giovinetto MB (2000) Spatial distribution of net surface mass balance on Greenland. Ann Glaciol 31: 126-132 
Final Version, January 17, 2005
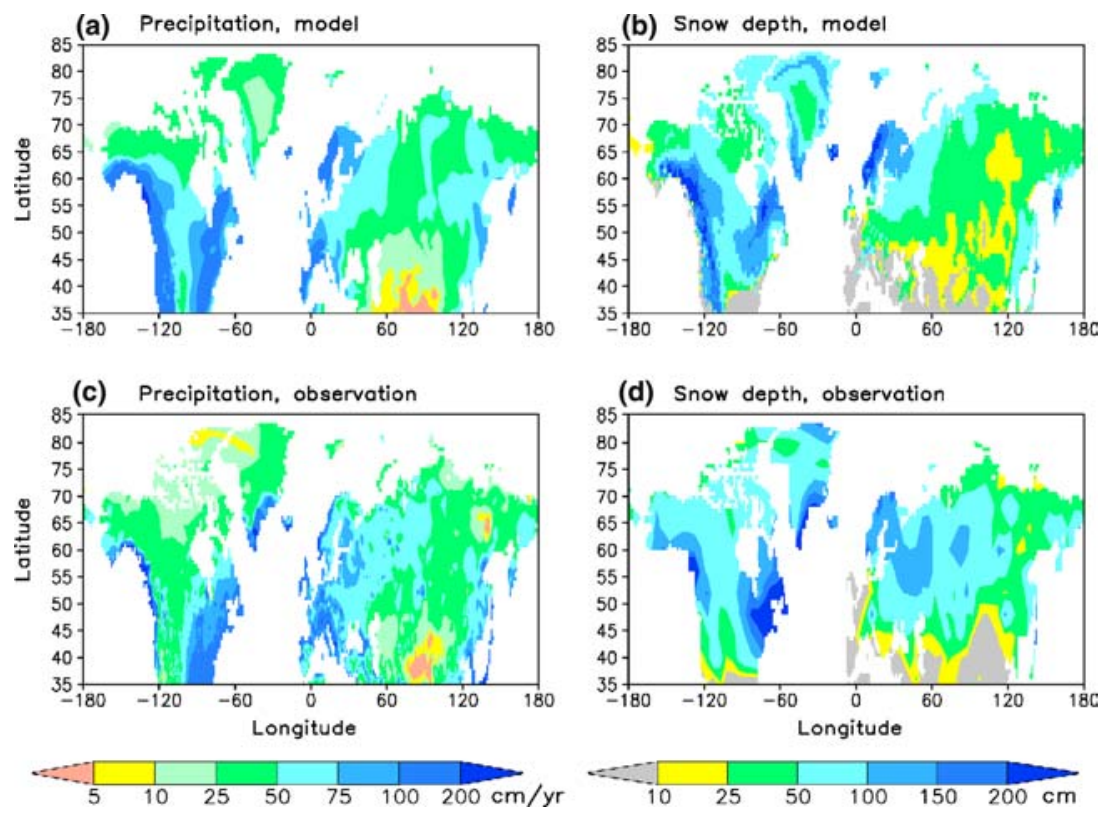

Figure 1: Present-day annual precipitation in centimetres per year $(\mathbf{a}, \mathbf{c})$ and February snow depth in centimetres $(\mathbf{b}, \mathbf{d})$; model results $(\mathbf{a}, \mathbf{b})$ and observations $(\mathbf{c}, \mathbf{d})$. 
(a) Area of positive mass balance

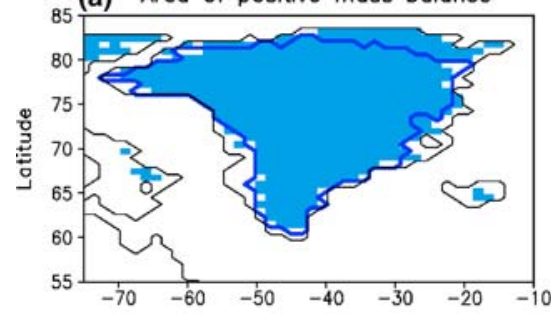

(c) Accumulation

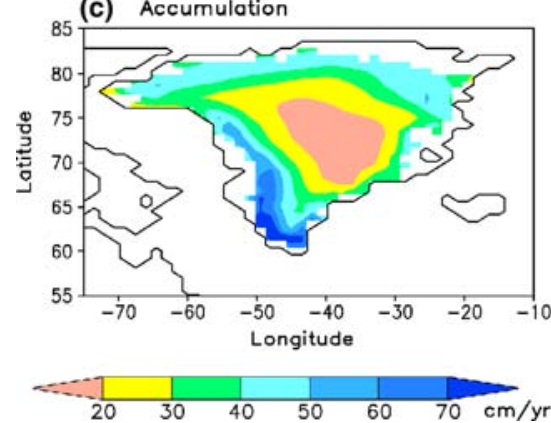

(b) Temperature

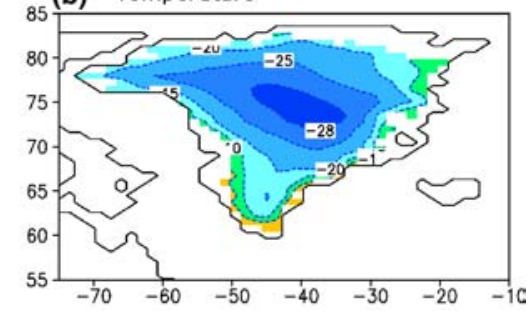

(d) Ablation

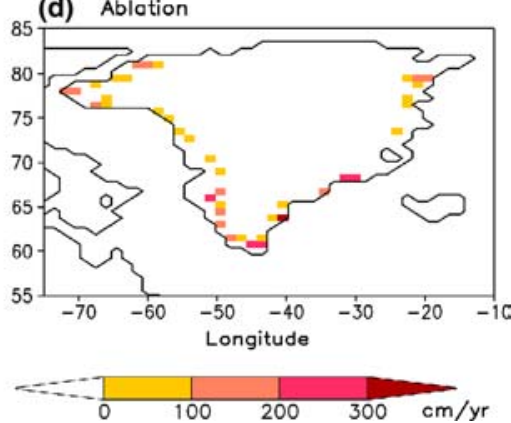

Figure 2: Simulated climatological forcing for the prescribed present-day Greenland ice sheet: a area of positive annual mass balance (shaded); solid line shows the observed extent of the Greenland ice sheet, $\mathbf{b}$ annual averaged surface temperature in ${ }^{\circ} \mathrm{C}, \mathbf{c}$ annual accumulation rate in centimetres of water equivalent per year, and $\mathbf{d}$ annual ablation rate in centimetres of water equivalent per year. 

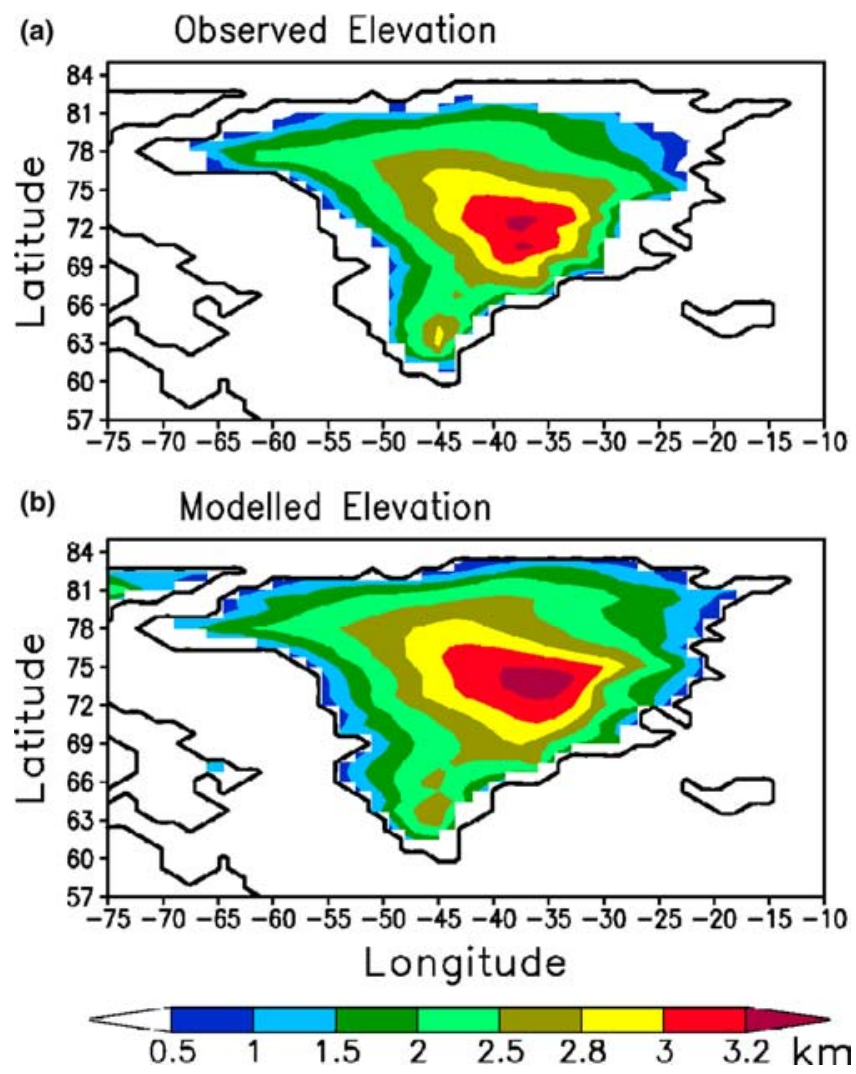

Figure 3: Surface elevation of the Greenland ice sheet in kilometres: a observed after Letréguilly et al. (1991), and b from a steady-state simulation with the fully coupled model. 

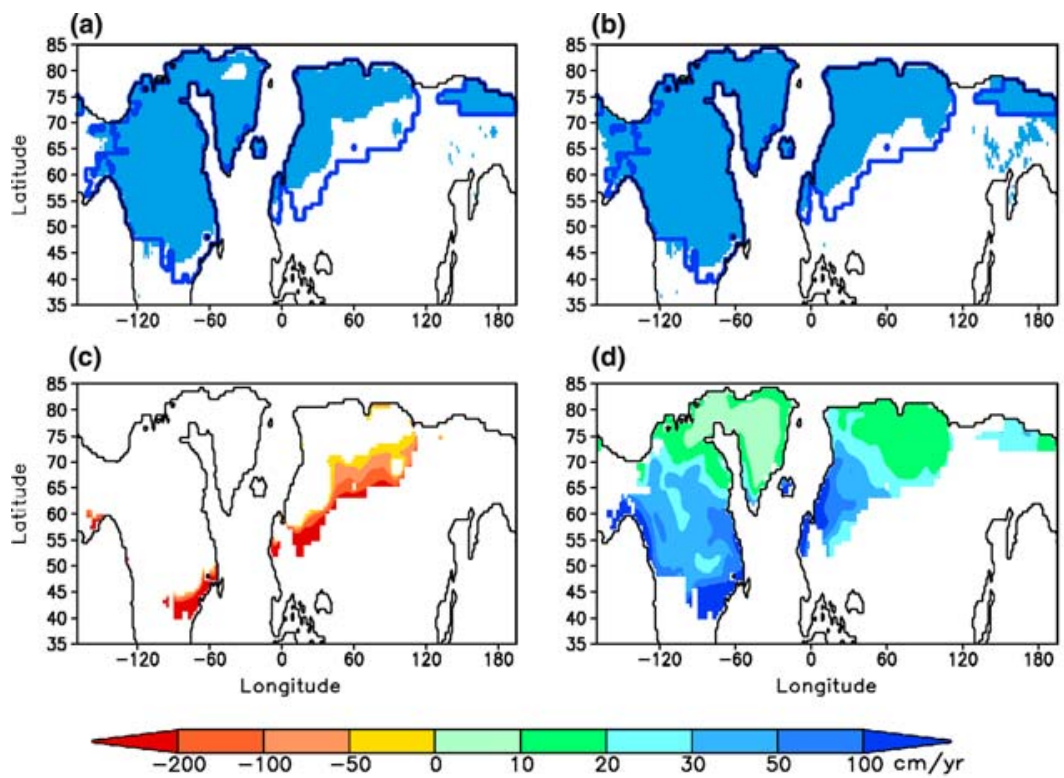

Figure 4: Simulated climatological forcing for the LGM conditions with prescribed (Peltier 1994) ice sheets: a, b simulated area of positive annual mass balance (shaded) for the LGM and modern dust-deposition rate, respectively. Solid lines indicate the margins of prescribed ice sheets after Peltier (1994), c annual ablation rate in centimetres of water equivalent per year for the experiment with the LGM dust-deposition rate, $\mathbf{d}$ annual accumulation rate in centimetres of water equivalent per year for the experiment with the LGM dust-deposition rate. 


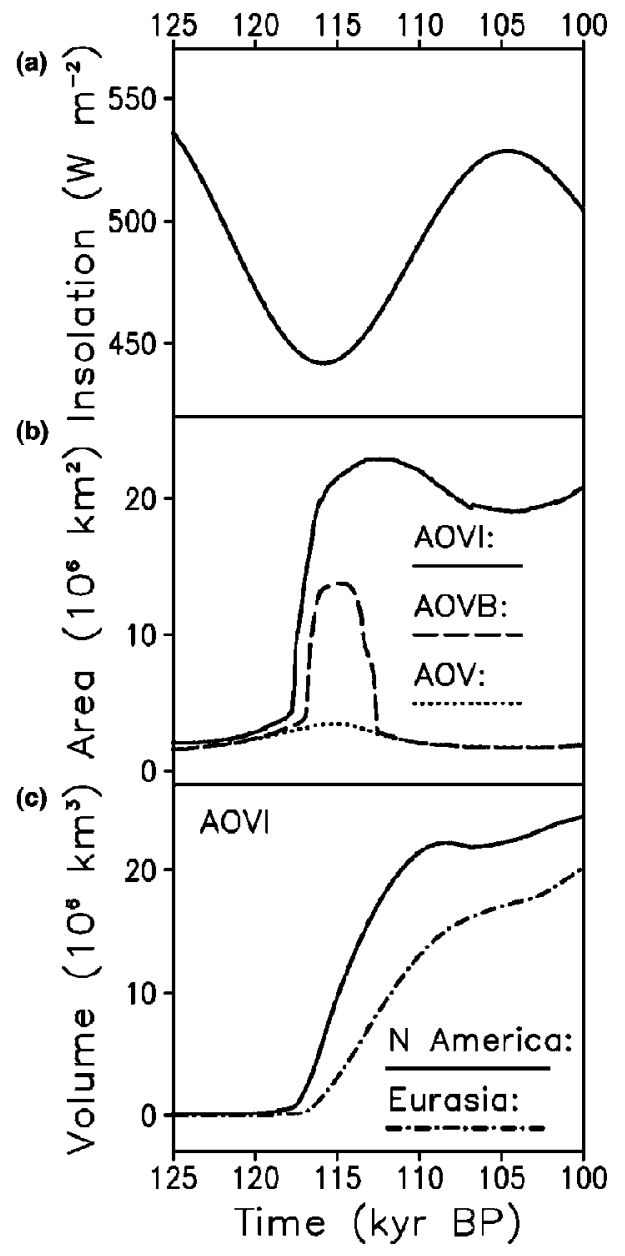

Figure 5: Time series between 125 and $100 \mathrm{kyr}$ BP: a maximum value of insolation - this value is close to the summer solstice at $65^{\circ} \mathrm{N}, \mathbf{b}$ area of permanent snow cover in $10^{6} \mathrm{~km}^{2}$, c ice volume $\left(10^{6} \mathrm{~km}^{3}\right)$ in North America (solid line) and in Eurasia (dashed-dotted line). For the Eurasian ice volume we excluded the Greenland ice sheet for simplicity here. Experiment AOVI is fully interactive including Atmosphere, Ocean, Vegetation and Ice sheets. In both experiments AOV and AOVB, the ice-sheet module is switched off. But in experiment AOVB, the area of perennial snow cover computed by SEMI is fed back to the climate module. 

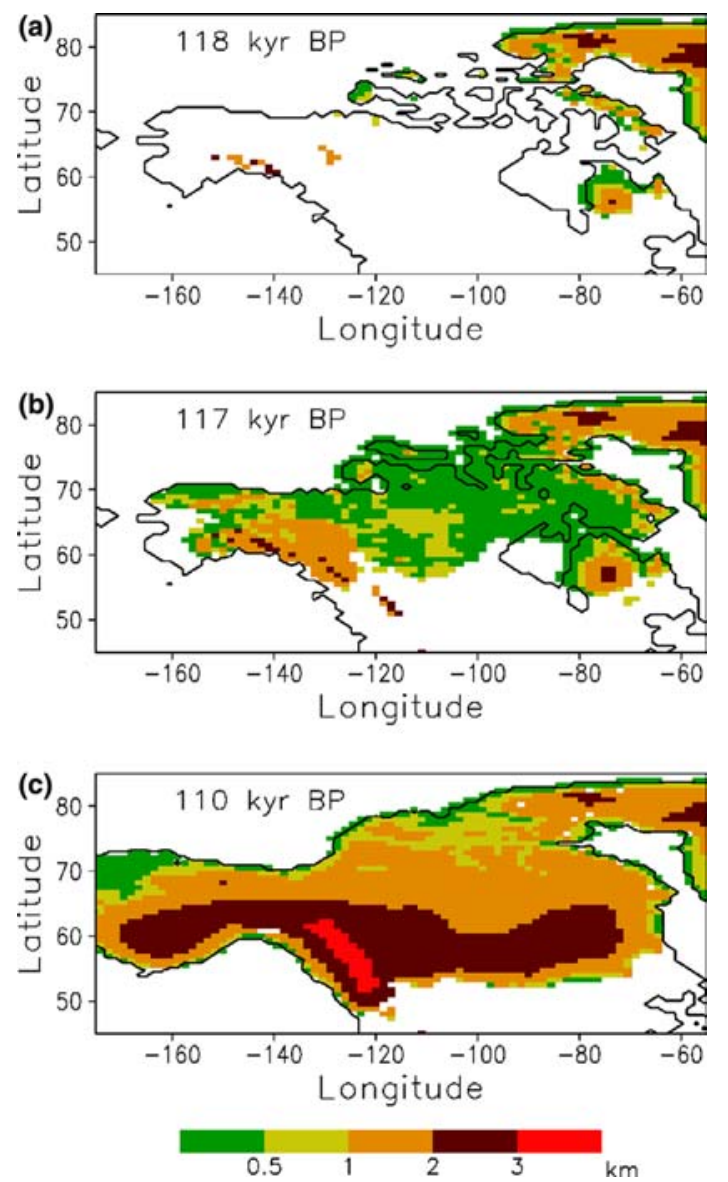

Figure 6: Surface elevation of the inland ice in North America in AOVI at a 118 kyr BP, b 117 kyr BP and c 110 kyr BP. The elevation is given in kilometres. 
Final Version, January 17, 2005
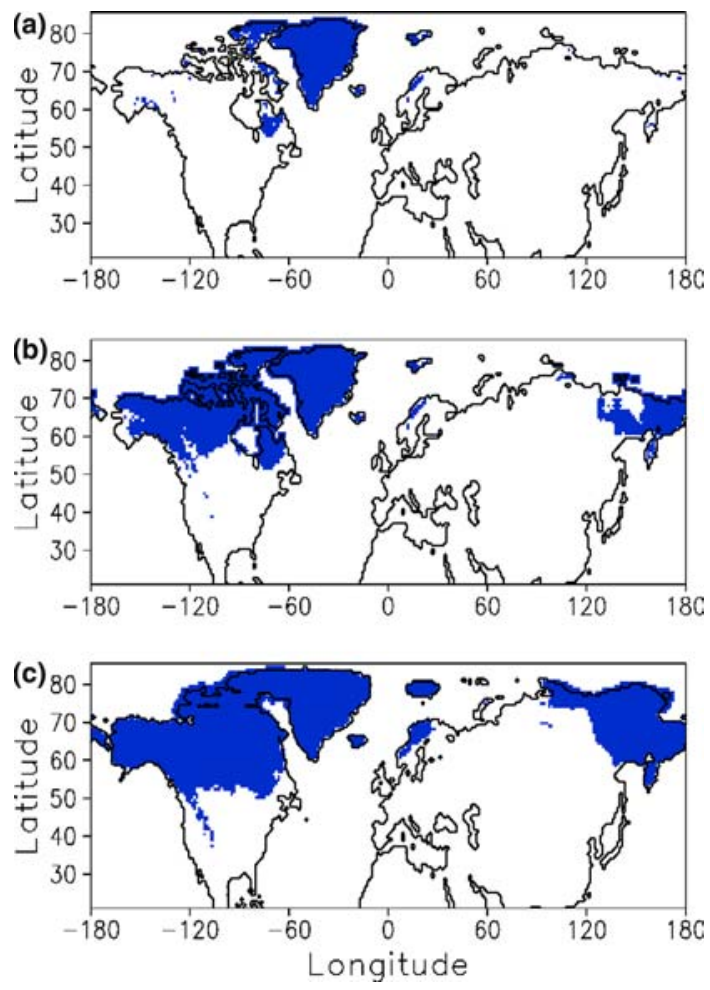

Figure 7: Areas on the Northern Hemisphere covered permanently with snow at 115 kyr BP in a AOV, b AOVB, and $\mathbf{c}$ AOVI. 

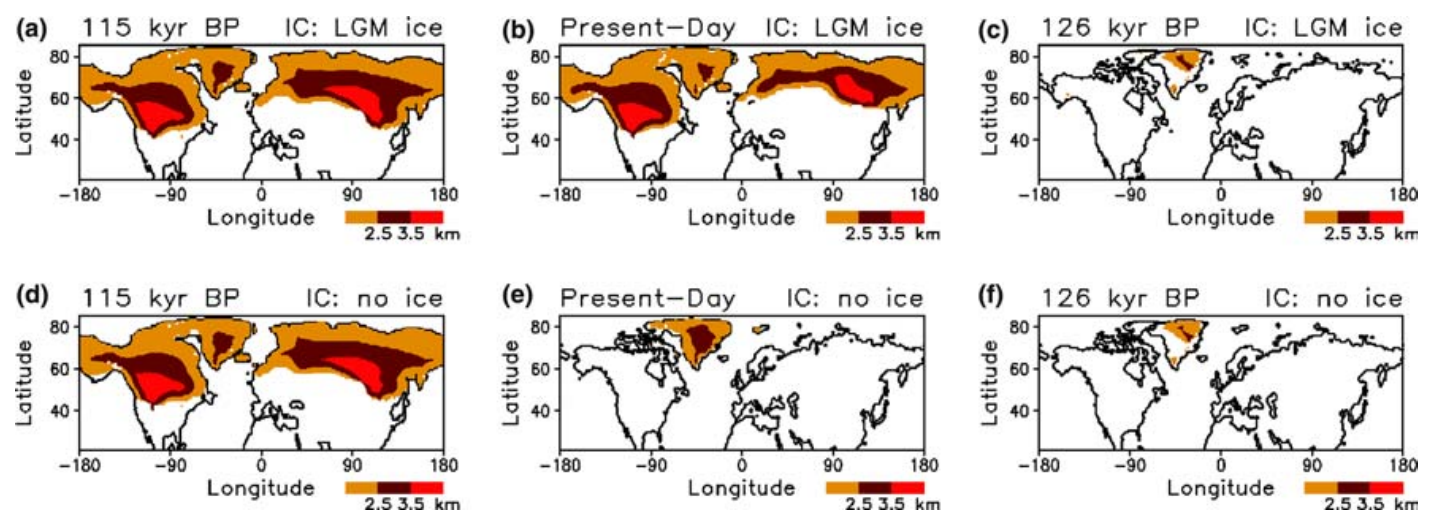

Figure 8: Surface elevation of the inland ice on the Northern Hemisphere for three different orbital configurations and two different initial conditions. The elevation is given in kilometres. All experiments are run with pre-industrial $\mathrm{CO}_{2}$ concentration. The model is integrated for 200 kyr to ensure that the model has obtained an equilibrium state. In the runs shown in the upper three panels ( $\mathbf{a}, \mathbf{b}$ and $\mathbf{c}$ ), the LGMice-sheet reconstruction of Peltier (1994) applies as initial condition ("IC: LGM ice"), while in the run depicted in the lower three panels ( $\mathbf{d}$, e and $\mathbf{f}$ ), the ice is allowed to build up from ice-free conditions ("IC: no ice"). Panels a and $\mathbf{d}$ refer to insolation computed from 115 kyr BP orbital parameters, $\mathbf{b}$ and $\mathbf{e}$ to present-day, and $\mathbf{c}$ and $\mathbf{f}$ to insolation evaluated for $126 \mathrm{kyr} \mathrm{BP}$ orbital parameters, respectively. 